\title{
Bioactive, functional and edible film-forming properties of isolated hazelnut (Corylus avellana L.) meal proteins
}

\author{
Levent Yurdaer Aydemir ${ }^{\mathrm{a}}$, Aysun Adan Gökbulut ${ }^{\mathrm{b}}$, Yusuf Baran ${ }^{\mathrm{b}}$, Ahmet Yemenicioğlu ${ }^{\mathrm{a}, *}$ \\ a Department of Food Engineering, Faculty of Engineering, Izmir Institute of Technology, Gülbahçe Köyü, Urla, Izmir 35430, Turkey \\ ${ }^{\mathrm{b}}$ Department of Molecular Biology and Genetics, Faculty of Science, Izmir Institute of Technology, Gülbahçe Köyü, Urla, Izmir 35430, Turkey
}

\section{A R T I C L E I N F O}

\section{Article history:}

Received 20 March 2013

Accepted 19 September 2013

\section{Keywords:}

Hazelnut meal

Protein

Bioactive

Functional properties

Edible film

\begin{abstract}
A B S T R A C T
This study aimed characterization of bioactive, functional and edible film making properties of isolated proteins from untreated (HPI), hot extracted (HPI-H), acetone washed (HPI-AW), and acetone washed and hot extracted (HPC-AW-H) hazelnut meals. The most bioactive protein extract was HPC-AW-H, followed by HPI-AW, HPI-H and HPI, based on antioxidant activity (TEAC and ORAC: 158 $-461 \mathrm{mmol}$ Trolox $/ \mathrm{kg}$ ), iron chelation (60.7-126.7 mmol EDTA $/ \mathrm{kg}$ ), angiotensin-converting enzyme inhibition ( IC $_{50}: 0.57-1.0 \mathrm{mg} / \mathrm{mL}$ ) and antiproliferative activity on colon cancer cells ( $\mathrm{IC}_{50}: 3.0-4.6 \mathrm{mg} /$ $\mathrm{ml}$ ). Protein contents of HPI, HPI-H and HPI-AW (93.3-94.5\%) were higher than that of HPC-AW-H (86.0\%), but HPC-AW-H showed the best pH-solubility profile. The extracts showed good oil absorption $(7.4-9.4 \mathrm{~g} / \mathrm{g}$ ) and foaming, but limited water holding and gelling capacities, and emulsion stability. The protein extracts gave transparent, yellowish to brownish and reddish colored and water soluble edible films. The HPI gave the lightest colored films with acceptable mechanical properties (elongation up to $144 \%$ and tensile strength up to $4.9 \mathrm{MPa}$ ). 1-D and 2-D electrophoresis clearly showed the molecular and isoelectric profiles of hazelnut proteins. The overall results of this study showed that the bioactive, solubility and gelation properties of hazelnut proteins could be improved by simple processes like acetone washing and/or heat treatment. The hazelnut proteins are valuable as multipurpose food ingredients.
\end{abstract}

(C) 2013 Elsevier Ltd. All rights reserved.

\section{Introduction}

The increasing global economic problems and consumer demands originated from health concerns, religious limitations and rising trend of vegetarianism have recently arisen an interest in the usage of functional plant based proteins as alternative to animal proteins in the food industry (Alonso, Beunza, Bes-Rastrollo, Pajares, \& Martínez-González, 2006; Dormont, 2002; Jenkins et al., 2002; Karim \& Bhat, 2009). The plant origin proteins are employed in different food systems due to their nutritive value, bioactivity and many different functional properties such as emulsifying activity, foam and gel formation, oil, water and flavor binding, increase of viscosity etc. (Arcan \& Yemenicioglu, 2010; Damodaran, 1996). Moreover, the good film forming properties of plant proteins make them potential candidate materials for developing edible films and plastic alternative biodegradable packaging materials (Bräuer, Meister, Gottlöber, \& Nechwatal, 2007).

\footnotetext{
* Corresponding author. Tel.: +90 (232) 7506292; fax: +90 (232) 7506196

E-mail address: ahmetyemenicioglu@iyte.edu.tr (A. Yemenicioğlu).
}

In industry, protein isolates, concentrates and hydrolyzates obtained from soybeans are used extensively in foods such as meat and dairy products, infant formulas, functional foods and nutraceuticals. The protein rich soy meals have now also become the major source of animal feeds in most of the world (FAO, 2002). However, due to the rapidly growing plant protein market there is a great competition to evaluate oil-seeds, fruits and vegetables, cereals and soy alternative legumes and their processing wastes as source of commercial proteins (Boye, Zare, \& Pletch, 2010; Moure, Sineiro, Domínguez, \& Parajó, 2006). A particular interest has been focused on protein of defatted meals obtained from oil industry. For example, bioactive and functional properties of protein extracted from meals of major oilseeds including sunflower, canola and rapeseed seeds have been investigated by different workers (Manamperi, Wiesenborn, Chang, \& Pryor, 2011; Megías et al., 2008; Salgado, Ortiz, Petruccelli, \& Mauri, 2012; Wu, Aluko, \& Muir, 2009; Yoshie-Stark, Wada, Schott, \& Wäsche, 2006). Salgado, Molina Ortiz, Petruccelli, and Mauri (2010) and Orliac, Rouilly, Silvestre, and Rigal (2002) investigated the potential of edible film making by using sunflower proteins while Jang, Lim, and Bin Song (2011) studied with edible films from rapeseed proteins. 
Besides oilseed protein, peanut meal and palm fruit meal proteins have also been evaluated for their bioactive, edible film making or functional properties to understand their value as alternative sources of functional proteins (Chee, Ling, \& Ayob, 2012; Jamdar et al., 2010; Ng, Ayob, Said, Osman, \& Ismail, 2013; Reddy, Jiang, \& Yang, 2012).

Hazelnut (Corylus avellana L.) belonging to the Betulaceae family is a very popular tree nut worldwide (Alasalvar et al., 2009). With its almost 650,000 metric tons of production Turkey is the largest producer of hazelnuts in the world and provides almost $85 \%$ of world hazelnut requirement (Demiryürek, Ceyhan, \& Bozoğlu, 2012). In world food industry, most of the hazelnuts are used as ingredients for confectionary and for production of hazelnut cream. Whole roasted hazelnuts are also popular as snack food. Recently, the edible oil production from hazelnuts has also become increasingly important since hazelnut oil has similar fatty acid profile with olive oil (Yalcin, Toker, \& Dogan, 2012). Due to its nutritive value and high protein content, the hazelnut meal obtained from oil extraction is mostly employed as animal feed (Xu \& Hanna, 2011). In fact, recent studies showed that the Turkish hazelnut meal can successfully be used in feeding juvenile rainbow trout (Doğan \& Erdem, 2010) and European sea bass (Emre, Sevgili, \& Şanlı, 2008) as alternative to fish meal and soybean meal. There are also studies to use Turkish hazelnut meal in feeding of broiler chickens (Erener, Ak, \& Ocak, 2009). Recently, Sharma, Su, Joshi, Roux, and Sathe (2010) studied the molecular and functional properties of different defatted nut flour proteins including hazelnut proteins. However, there are no attempts to evaluate the hazelnut meal obtained from commercial oil extraction for production of value added products including protein concentrates and isolates, and protein based edible films suitable for the food industry. This study is significant in that it is the first study to characterize the bioactive, functional and edible film making properties of different protein isolates and concentrates obtained from hazelnut (C. avellana L.) meal by the commercially suitable purification procedures. The molecular and isoelectric properties of hazelnut proteins have also been characterized with $1 \mathrm{D}$ and 2D electrophoresis to prepare basis for advanced identification, characterization and purification studies. This work contributes to develop alternative commercial proteins for use of food, feed, drug and cosmetic industry.

\section{Materials and methods}

\subsection{Materials}

The hazelnut meal was kindly provided by Altaş Gıda, Ordu (Turkey). ABTS (2,2'-Azino-bis (3-ethylbenzo-thiazoline-6-sulfonic acid)), Angiotensin converting enzyme from rabbit lung, FAPGG (N-[3-(2-Furyl)acryloyl]-Phe-Gly-Gly), Captopril, MTT formazan were purchased from Sigma Chem. Co. (St. Louis, MO, USA). AAPH (2,2'-Azobis[2-methyl-propionamidine]) dihydrochloride was purchased from Sigma-Aldrich Chemie GmbH (Germany). Ferrozine (3-(2-Pyridyl)-5,6-diphenil-1,2,4-triazine-4'4' -disulfonic acid monosodium salt) and fluorescein sodium salt were purchased from Fluka (St. Louis, MO, USA). Dimethyl sulfoxide was purchased from Santa Cruz Biotechnology, Inc. (Germany). RPMI medium 1640 was purchased from Gibco by Life Technologies (Carlsbad, CA, USA).

\subsection{Composition of hazelnut meal}

The total protein content of hazelnut meal was determined by using the classical Kjeldahl method conducted at an automated testing machine (Gerhard Vapodest 50s and Kjeldahl Therm, Germany). The total protein contents (TPC) were calculated by using conversion factor of 6.25 . Total lipid content and ash contents of hazelnut meal were determined according to AOAC 948.22 and AOAC 950.49 standard methods (AOAC, 1998), respectively. Moisture content of hazelnut meal was determined according to the ISO method $\neq 665$ by drying of the meal samples for $3 \mathrm{~h}$ at $103^{\circ} \mathrm{C}$ (ISO, 2000). The samples were then weighted after cooling down in a desiccator and the drying was continued with $1 \mathrm{~h}$ drying periods until difference between two successive weightings was equal to or less than $0.005 \mathrm{~g}$. The average of three measurements was used for all compositional analysis tests. All results were given as percent in dry weight basis. The total carbohydrate content was calculated by subtracting percentages of total protein, lipid and ash contents from hundred.

\subsection{Protein isolation from hazelnut meal}

For this purpose $50 \mathrm{~g}$ of hazelnut meal was rehydrated overnight in $500 \mathrm{~mL}$ of deionized water at $4{ }^{\circ} \mathrm{C}$. The mixture was then homogenized in a Waring blender for $2 \mathrm{~min}$. The rough particles of insoluble debris were then removed by filtering through cheesecloth and the thinned slurry was used in protein isolation. For protein isolation the $\mathrm{pH}$ of the slurry was adjusted to 9.5 with $1 \mathrm{~mol} / \mathrm{L} \mathrm{NaOH}$. To obtain the hazelnut meal protein isolate (HPI) this slurry was magnetically stirred for $45 \mathrm{~min}$ at room temperature. To obtain the hot extracted hazelnut meal protein isolate (HPI-H) the slurry at pH 9.5 was heated to $85{ }^{\circ} \mathrm{C}$ and maintained at this temperature for 30 min under stirring. The heated extract was then cooled to room temperature under continuous stirring for $15 \mathrm{~min}$. After that the extract of HPI or HPI-H was clarified by centrifugation for $30 \mathrm{~min}$ at $15,000 \times \mathrm{g}\left(\right.$ at $\left.4{ }^{\circ} \mathrm{C}\right)$. The protein in the obtained supernatants was then precipitated by the isoelectric precipitation method (IEP) by adjusting the $\mathrm{pH}$ of extracts to 4.5 with $1 \mathrm{~mol} / \mathrm{L}$ acetic acid. The precipitated proteins were collected with centrifugation and resuspended in distilled water. The $\mathrm{pH}$ of the suspensions was again adjusted to 4.5 and proteins were once more precipitated and collected with centrifugation. Finally, the obtained proteins were suspended in distilled water by adjusting their $\mathrm{pH}$ to 7.0 and lyophilized (Labconco, FreeZone, 6 L, Kansas City, MO, USA). The unheated and heated isolates obtained were named as HPI and HPI-H and stored at $-18{ }^{\circ} \mathrm{C}$ until they were analyzed.

\subsection{Protein isolation from acetone washed hazelnut meal}

For this purpose $50 \mathrm{~g}$ of meal was first rehydrated overnight in $500 \mathrm{~mL}$ of deionized water at $4{ }^{\circ} \mathrm{C}$. The mixture was filtered from the cheesecloth and the hydrated softened meal pellets retained on the cheesecloth were collected. The collected meal was then mixed with $200 \mathrm{~mL}$ of cold acetone at $-18{ }^{\circ} \mathrm{C}$, and the mixture was homogenized in a Waring blender for $3 \mathrm{~min}$. After that the slurry obtained was filtered under vacuum from Buncher funnel containing a Whatman No.1 filter paper and the solid residue remained on the filter paper was collected. The homogenization with $200 \mathrm{~mL}$ cold acetone and filtration were then repeated for two more times for the collected residue and it was left overnight to evaporate the acetone. For protein extraction, $20 \mathrm{~g}$ of acetone washed meal powder was suspended in $250 \mathrm{~mL}$ deionized water and the $\mathrm{pH}$ of the slurry was adjusted to 9.5 with $1 \mathrm{~mol} / \mathrm{L} \mathrm{NaOH}$. To obtain the acetone washed hazelnut meal protein isolate (HPI-AW) this slurry was mixed with magnetic stirring for $45 \mathrm{~min}$ at room temperature. The heated and acetone washed hazelnut meal protein concentrate (HPC-AW-H) was obtained by heating the slurry at $\mathrm{pH} 9.5-85{ }^{\circ} \mathrm{C}$ and maintaining it at this temperature for 30 min under continuous stirring. The heated extract was cooled at room temperature under continuous stirring for $15 \mathrm{~min}$. The HPI-AW or HPC-AW-H obtained was then clarified by centrifugation for $30 \mathrm{~min}$ at $15,000 \times \mathrm{g}$ (at $4{ }^{\circ} \mathrm{C}$ ). The protein in the obtained supernatants was then 
precipitated by the classical IEP method and lyophilized as described in Section 2.3. The unheated and heated isolates and concentrates were named as HPI-AW and HPC-AW-H, respectively, and stored at $-18{ }^{\circ} \mathrm{C}$ until they were analyzed.

\subsection{Total protein content and protein solubility of isolated hazelnut meal proteins}

The total protein contents of isolated protein were determined by the Kjeldahl method (see Section 2.2). The extracts with total protein contents higher than $90 \%$ were designated as hazelnut protein isolate (HPI), while extracts having lower total protein content than $90 \%$ were designated as hazelnut protein concentrate (HPC). The solubilities of isolated proteins were determined at different pHs between 2 and 11 . Twenty mg portions of lyophilized protein were suspended in $10 \mathrm{~mL}$ of deionized water and the $\mathrm{pH}$ of the suspensions was adjusted to different $\mathrm{pH}$ values between 2 and 11 by using $0.01 \mathrm{~mol} / \mathrm{L} \mathrm{NaOH}$ or $0.01 \mathrm{~mol} / \mathrm{L}$ acetic acid solutions. The suspensions were then clarified by centrifugation at $4500 \times \mathrm{g}$ for $20 \mathrm{~min}$ at $4{ }^{\circ} \mathrm{C}$. The soluble protein content (SPC) of the supernatants was determined by the Bradford method using bovine serum albumin (BSA) as standard.

\subsection{Bioactive properties of isolated hazelnut meal proteins}

\subsubsection{Antioxidant potential of isolated proteins}

The antioxidant potentials of lyophilized protein extracts were evaluated by determination of their free radical scavenging capacity with oxygen radical absorbance capacity (ORAC) and trolox equivalent antioxidant capacity (TEAC) tests and iron chelating capacities (ICC). The samples used in the determination of antioxidant potential were prepared in distilled water. The lyophilized protein extracts were suspended in distilled water $(0.01 \mathrm{~g}$ protein extract/mL water), dissolved by magnetic stirring for $30 \mathrm{~min}$ at room temperature and clarified by centrifugation at $15,000 \times \mathrm{g}$ for $20 \min \left(4^{\circ} \mathrm{C}\right)$.

The ORAC method was applied by slightly modifying the procedure given by Xu and Chang (2007). Briefly, $20 \mu \mathrm{L}$ of protein sample was pipetted into a 96 well plate (black). Then, $200 \mu \mathrm{L}$ of $0.096 \mu \mathrm{mol} / \mathrm{L}$ fluorescein solution prepared in $75 \mathrm{mmol} / \mathrm{L}$ phosphate buffered saline (PBS) (contained $150 \mathrm{mmol} / \mathrm{L} \mathrm{NaCl}$ ) at $\mathrm{pH} 7.4$ was added into each well and the mixtures were incubated at dark for $20 \mathrm{~min}$ at $37{ }^{\circ} \mathrm{C}$. The reactions were started by adding $20 \mu \mathrm{L}$ of $100 \mathrm{mmol} / \mathrm{L}$ AAPH prepared in PBS. The fluorescence of reaction mixture was monitored periodically for $40 \mathrm{~min}$ at the excitation wavelength of $485 \mathrm{~nm}$ and emission wavelength of $520 \mathrm{~nm}$ by using a Varioskan Flash spectrophotometer (3001, Finland). The measurements were conducted as two repetitions and three replicates and calculated ORAC values were expressed as mmol trolox equivalents per $\mathrm{kg}$ of lyophilized protein extract.

The TEAC method was applied against ABTS free radical by the method of Re et al. (1999). The reaction mixture was prepared by mixing 25, 50 and $75 \mu \mathrm{l}$ of sample with $2 \mathrm{~mL}$ of ABTS free radical cation solution prepared in PBS at $\mathrm{pH}$ 7.4. The reduction in absorbance values was recorded at $734 \mathrm{~nm}$ with a spectrophotometer (Shimadzu Model 2450, Japan). The area under the curve (AUC) value of samples was calculated as described in the given method (for test periods of 1, 3, 6, 9,12, and $15 \mathrm{~min}$ ). All measurements were conducted for three times, and TEAC values were expressed as mmol trolox equivalents per $\mathrm{kg}$ of lyophilized protein extract.

The ICC of extracts were determined according to the spectrophotometric method given by Arcan and Yemenicioglu (2007). The results were expressed as mmol EDTA per $\mathrm{kg}$ of lyophilized protein extract. The average of three replicates was used to calculate the iron chelating capacity.

\subsubsection{Antiproliferative activity of isolated proteins}

In order to evaluate their potential anticancerogenic effects the isolated proteins were tested for their antiproliferative activity against CCC221/DLD-1 colon cancer cells by MTT cell proliferation assay (Piskin et al., 2007). The cells obtained from the German Collection of Microorganisms and Cell Cultures (Germany) were cultured in RPMI-1640 growth medium containing 10\% fetal bovine serum and $1 \%$ penicillin-streptomycin (Gibco by Life Technologies) at $37{ }^{\circ} \mathrm{C}$ and $5 \% \mathrm{CO}_{2}$. Briefly, 96-well plates were seeded with $5 \times 10^{3}$ cells per well containing $100 \mu \mathrm{L}$ of the growth medium in the absence or presence of increasing concentrations of the protein extracts dissolved in ultrapure water. The cells were incubated at $37{ }^{\circ} \mathrm{C}$ and $5 \% \mathrm{CO}_{2}$ for 48 and $72 \mathrm{~h}$. After that the cells were treated with $20 \mu \mathrm{L}$ MTT ( $5 \mathrm{mg} / \mathrm{mL}$ in PBS) for $3 \mathrm{~h}$ at $\mathrm{CO}_{2}$ incubator. The plates were centrifuged at $1800 \mathrm{rpm}$ for $10 \mathrm{~min}$, supernatants were removed from the plates and the MTT crystals were then dissolved by adding $100 \mu \mathrm{L}$ dimethyl sulfoxide (DMSO) into each well. The plates were shaken for 5 min to dissolve crystals more effectively and their absorbance was determined with a spectrophotometer at $570 \mathrm{~nm}$. The $\mathrm{IC}_{50}$ values were determined as mg protein extract per $\mathrm{ml}$ from plots of \% cell proliferation vs. protein extract concentration.

\subsubsection{Antihypertensive activity of isolated proteins}

The antihypertensive activity of protein extracts was determined by measuring their inhibitory effects on Angiotensinconverting enzyme (ACE) according to the method described by Shalaby, Zakora, and Otte (2006) with minor modifications. Briefly, $10 \mu \mathrm{L}$ of 0.25 units/mL ACE prepared in $0.01 \mathrm{~mol} / \mathrm{L} \mathrm{PBS} \mathrm{(} \mathrm{NaCl}$ concentration: $0.5 \mathrm{~mol} / \mathrm{L})$ at $\mathrm{pH} 7.0$ was mixed with $10 \mu \mathrm{L}$ of protein extract solution at different concentrations $(1,2,3,4,6,8,12,16 \mathrm{mg} /$ $\mathrm{mL})$. The enzyme-protein mixture was incubated for $15 \mathrm{~min}$ at $37^{\circ} \mathrm{C}$ and the enzymatic reaction was initiated by adding $150 \mu \mathrm{L}$ $1.75 \mathrm{mmol} / \mathrm{L}$ FAPGG substrate solution (at $37^{\circ} \mathrm{C}$ ) prepared in PBS into this mixture. The assay was performed in 96 well microtiter plates (UV flat bottom, 8404, Thermo Fisher Scientific, Waltham, MA, USA) using the Varioskan Flash spectrophotometer. The absorbance of the reaction mixture was monitored at $340 \mathrm{~nm}$ for $30 \mathrm{~min}$ at $37^{\circ} \mathrm{C}$ and the ACE activity was determined from the slope of the initial linear portion of absorbance-time curve. The ACE inhibition (\%) was calculated according to the following formula of $\%$ ACE inhibition $=[1-$ (activity in presence of protein extract $]$ activity of control) $] \times 100$. The $\mathrm{IC}_{50}$ values were determined as $\mathrm{mg}$ protein extract per $\mathrm{ml}$ from plots of $\%$ ACE inhibition versus protein extract concentration. The captopril was used as positive control.

\subsection{Functional properties of isolated proteins}

Water (WAC) and oil absorption capacity (OAC), emulsifying activity (EA) and emulsion stability (ES), foaming activity (FA) and foam stability (FS) of protein extracts were determined exactly as described in Aydemir and Yemenicioglu (2013). The gel formation capacity of proteins was determined according to the method given by Aydemir and Yemenicioglu (2013) with slight modifications. The slight modifications include the concentrations of protein extracts which were between 1 and 20\% (w/v) in the current study. Moreover, although the gel formation was detected similarly by observing the flow characteristics of tube contents when tubes were turned upside down, the changes in protein consistency and gel formation in the current study were evaluated and expressed differently according to the following criteria: + : increased viscosity-first signs of gelation; ++ : slush-like unfixed gel which slipped within tube when it was turned upside down; +++ : fixed hard gel which did not slip within tube when it was turned upside down (used for determination of least gelation concentration 
(LGC)). All other conditions were exactly same with those reported in the specified reference. The gelling properties of hazelnut protein extracts were compared with those of commercial soy and whey protein isolates kindly provided by Eurodona Rohstoffe GmbH (Dunasoy 90, $0.90 \mathrm{~g}$ protein/g, Germany) and Davisco Foods International Inc. (BiPRO, $0.98 \mathrm{~g}$ protein/g, MN, USA), respectively.

\subsection{Edible film making properties of isolated hazelnut proteins}

\subsubsection{Film making method}

The edible film making properties of protein extracts were compared at optimal protein and plasticizer concentrations determined during preliminaries. Briefly, solution of protein extracts at the concentration of $10 \%$ or $12.5 \%(\mathrm{w} / \mathrm{w})$ was prepared with deionized water by continuous stirring for $30 \mathrm{~min}$ at room temperature. Then, the glycerine used as a plasticizer was added into protein solution until its concentration reached $30 \%$ of protein extract in the film making solution. The $\mathrm{pH}$ of the solution was adjusted to 11.0 with $1 \mathrm{~mol} / \mathrm{L} \mathrm{NaOH}$ and it was heated at $90^{\circ} \mathrm{C}$ for 30 or $60 \mathrm{~min}$. The film making solution was cooled to room temperature and it was homogenized (Heidolph, Germany, rotor $\Phi=6.6 \mathrm{~mm}$ tip) at $10,000 \mathrm{rpm}$ for 4 min with a homogenizerdisperser. Then, $5 \mathrm{~g}$ portions of film making solution was poured into plastic petri dishes (diameter: $8.8 \mathrm{~cm}$ ) and dried in a controlled test cabinet (TK 120, Nüve, Turkey) at $25{ }^{\circ} \mathrm{C}$ and $50 \%$ relative humidity (RH) for $24 \mathrm{~h}$. The thicknesses of the films were determined by SEM (Philips XL 30S FEG, FEI Company, Netherlands). Films were prepared for SEM by crashing, following freezing in liquid nitrogen. The thickness of the films was measured by using Scandium software from SEM cross-sectional views of films (Olympus Soft Imaging Solutions).

\subsubsection{Solubility tests of films}

To determine their solubility properties the dried edible films cut into $2 \times 2.5 \mathrm{~cm}$ pieces were placed into Petri dishes (diameter $8 \mathrm{~cm}$ ) containing $10 \mathrm{~mL}$ deionized water at $25^{\circ} \mathrm{C}$. The Petri dishes were sealed and then shaken at $160 \mathrm{rpm}$ for $3 \mathrm{~h}$ using an orbital shaker (IKA, OS 5 basic, Germany) placed in an incubator working at $25^{\circ} \mathrm{C}$ and $50 \% \mathrm{RH}$. Fifty microliter portions of samples were taken from the test mediums at different time intervals and their soluble protein content was determined by the Bradford Method. The results were expressed as amounts of solubilized protein as \% of total film protein at different time intervals.

\subsubsection{Mechanical properties of films}

Tensile strength at break and elongation at break were determined by a Texture Analyser TA-XT2 (Stable Microsystems, Godalming, UK) according to ASTM Standard Method D 882-02 (ASTM, 2002). The dried films were tested for their mechanical properties after an additional conditioning conducted at $25^{\circ} \mathrm{C}$ and $50 \% \mathrm{RH}$ for $48 \mathrm{~h}$ in the controlled test cabinet. During tests, the films were cut into $5 \mathrm{~mm}$ wide and $70 \mathrm{~mm}$ length strips. The initial grip distance was $50 \mathrm{~mm}$ and crosshead speed was $25 \mathrm{~mm} / \mathrm{min}$. At least five replicates of each film were tested.

\subsubsection{Color of films}

The color of the films was determined using a colorimeter (chromometer type CR-400, Minolta Sensing, Osaka, Japan). The films cut into $6 \times 6 \mathrm{~cm}$ pieces and their color coordinates were determined after the white calibration for illuminant $D_{65}$. A white background was placed on the film, and the color measurements were performed at five different positions. Average CIE $L^{*}, a^{*}$ and $b^{*}$ values were determined to investigate the changes in lightness, redness-greenness and yellowness-blueness of films, respectively.

\subsection{Classical 1-D SDS-PAGE and 2-D electrophoresis of isolated proteins}

The classical one dimensional (1-D) SDS-PAGE of different isolated proteins were conducted on a discontinuous buffered system according to Laemmli method using $15 \%(\mathrm{w} / \mathrm{v})$ separating gel and 5\% (w/v) stacking gel (Dunn, 1989). Lyophilized samples were directly solubilized in sample buffer and centrifuged at $15,000 \times g$ for $30 \mathrm{~min}$. The samples were then heated for $5 \mathrm{~min}$ in the boiling water before electrophoresis applied as described in Arcan and Yemenicioglu (2010). The protein bands were stained by the silver staining method described by Blum, Beier, and Gross (1987). A wide molecular weight range molecular marker (Thermo PageRuler Prestained Protein Ladder $10-170 \mathrm{kDa}$ ) was used to characterize the obtained protein bands (Thermo Scientific).

The two dimensional (2-D) electrophoresis (isoelectric focusing and SDS-PAGE) was applied to a selected isolate (HPI-AW) by using the ReadyPrep ${ }^{\mathrm{TM}}$ 2-D Starter Kit (BioRad Laboratories Inc.) according to product instructions manual. The details of this method were described previously by Arcan and Yemenicioglu (2010). Unstained Protein Molecular Weight Marker, 14.4-116 kDa (Bio Basic Inc.) and 2-D SDS-PAGE standard, pI range 4.5-8.5, (BioRad) were used as marker.

\subsection{Statistical analysis}

Statistical analysis was carried out by using "One-Way ANOVA" with a significance threshold of $P<0.05$ as determined by Fisher's protected least significant difference method. Minitab ${ }^{\circledR} 15$ (Minitab Inc., USA) software was used in analysis.

\section{Results and discussions}

\subsection{Composition of hazelnut meal}

The compositional analysis of hazelnut meal obtained from oil extraction showed the presence of $54.4 \%$ protein, $3.1 \%$ lipid, $7.0 \%$ ash and $35.5 \%$ carbohydrate in dry weight of this waste. The TPC determined for the hazelnut meal is higher than those of $46.8 \%$ determined by Emre et al. (2008) for Turkish hazelnut meal and those of $44.8 \%$ determined by Dogan and Erdem (2010) for the dry weight of similar meals. These results clearly showed that the protein content of hazelnut meal was comparable with that of soybean meal which could vary between $48.5 \%$ and $58.1 \%$ in dry weight basis (Thakur \& Hurburgh, 2007). Moreover, it also appeared that the hazelnut meal used in this work had higher protein content than sunflower and rapeseed meals which reported to contain TPCs of 32 and 35\% in dry weight basis, respectively (Lomascolo, Uzan-Boukhris, Sigoillot, \& Fine, 2012). Thus, it can be concluded that the Turkish hazelnut meal is a good source for protein extraction.

\subsection{Total protein content of isolated hazelnut meal protein}

The protein extracts used in this study were obtained directly from meal, or from acetone washed meal to eliminate the oxidized lipid residues and brown phenolic pigments which could interact with the proteins and modify their properties (Aewsiri et al., 2009; Tsai \& She, 2006). The extraction was conducted at room temperature to obtain total soluble protein fractions or at $85^{\circ} \mathrm{C}$ to denature and eliminate the heat labile protein and other heat labile impurities which might form haze or precipitate during food processing and storage.

The protein yields from hazelnut meal were $0.09,0.10,0.17$, and $0.18 \mathrm{~g}$ protein/g dry meal for the extracts of HPC-AW-H, HPI-AW, 
Table 1

Bioactive properties of hazelnut meal protein extracts.

\begin{tabular}{|c|c|c|c|c|c|c|c|}
\hline \multirow[t]{2}{*}{ Protein extract } & \multirow[t]{2}{*}{$\mathrm{TPC}(\%)$} & \multirow[t]{2}{*}{ TEAC (mmol Trolox/kg) } & \multirow[t]{2}{*}{ ORAC (mmol Trolox $/ \mathrm{kg})$} & \multirow[t]{2}{*}{ ICC (mmol EDTA/kg) } & \multirow{2}{*}{$\begin{array}{l}\text { ACE inh. } \mathrm{IC}_{50} \\
(\mathrm{mg} / \mathrm{mL})\end{array}$} & \multicolumn{2}{|l|}{ Antiproliferative act. } \\
\hline & & & & & & $\mathrm{IC}_{50}-48 \mathrm{~h}(\mathrm{mg} / \mathrm{mL})$ & $\mathrm{IC}_{50}-72 \mathrm{~h}(\mathrm{mg} / \mathrm{mL})$ \\
\hline HPI & $94.2 \pm 0.3 b^{a}$ & $158 \pm 0.6 \mathrm{~d}$ & $219 \pm 8 d$ & $61 \pm 8.4 d$ & $1.0 \pm 0.01 \mathrm{a}$ & $4.6 \pm 0.1 \mathrm{a}$ & $3.4 \pm 0.1 \mathrm{a}$ \\
\hline HPI-H & $94.5 \pm 0.5 b$ & $193 \pm 2.5 c$ & $337 \pm 7 c$ & $127 \pm 0.7 c$ & $0.82 \pm 0.01 b$ & $3.8 \pm 0.2 b$ & $3.1 \pm 0.2 b$ \\
\hline HPI-AW & $93.3 \pm 0.5 b$ & $254 \pm 4.2 b$ & $387 \pm 14 b$ & $64 \pm 2.7 b$ & $0.87 \pm 0.01 c$ & $3.6 \pm 0.2 b$ & $3.0 \pm 0.1 b$ \\
\hline HPC-AW-H & $86.0 \pm 2.9 a$ & $365 \pm 1.8 \mathrm{a}$ & $461 \pm 29 a$ & $101 \pm 2.0 \mathrm{a}$ & $0.57 \pm 0.02 \mathrm{~d}$ & $3.4 \pm 0.2 b$ & $3.1 \pm 0.1 b$ \\
\hline
\end{tabular}

${ }^{a}$ Different letters in each column show significant differences at $P<0.05$.

b $\mathrm{IC}_{50}$ values were determined for $48 \mathrm{~h}$ and $72 \mathrm{~h}$ incubation of cancer cells with the isolates.

HPI-H, and HPI, respectively. On the other hand, the TPCs of proteins isolated from hazelnut meal by different treatments varied between $86 \%$ and $94.5 \%$ (Table 1 ). The TPCs of HPI, HPI-H and HPIAW were not significantly different $(P>0.05)$, but HPC-AW-H had significantly lower protein content than the other extracts. These findings suggested that the classical unfolding effects of acetone on proteins (Brandts \& Hunt, 1967; Roe, 2001) increased the proteinprotein interactions and led the precipitation of proteins. Moreover, it also appeared that the heating of acetone treated proteins caused further insolubilization of a specific heat labile HPC-AW-H fraction during extraction.

\subsection{Protein solubility of isolated hazelnut meal proteins}

The protein extracts gave a $U$ shaped solubility profile between pH 2.0 and 11.0 with minimal solubility at $\mathrm{pH} 4.5$ which was also employed during purification with IEP (Fig. 1). This profile is quite similar with those of soybean meal proteins and other nut proteins from defatted cashew nut, walnut and brazil nut (Neto, Narain, Silva, \& Bora, 2001; Ogunwolu, Henshaw, Mock, Santros, \& Awonorin, 2009; Ramos \& Bora, 2005; Swamylingappa \& Srinivas, 1994; Sze-Tao \& Sathe, 2000). For HPI-AW, HPC-AW-H and HPI, the maximal solubility was observed at $\mathrm{pH} 2.0$ while HPI-H showed 2.5-3.0 fold lower solubility then these proteins at the indicated acidic $\mathrm{pH}$ value. At $\mathrm{pH}$ 3.0, the HPI-AW and HPC-AW-H showed 2.0-2.5 folds higher solubility than HPI and HPI-H. This result clearly showed that the acetone washing of meal contributed to increased solubility of protein at acidic $\mathrm{pH}$ values. The HPI and HPI$\mathrm{H}$ had similar $\mathrm{pH}$-solubility profiles between $\mathrm{pH} 3.0$ and $\mathrm{pH}$ 7.0, but HPI-H had slightly higher solubility than HPI between $\mathrm{pH} 8.0$ and 10. The HPC-AW-H and HPI-AW also showed similar solubility profiles at alkaline pH values, but HPC-AW-H had 1.9 and 1.4 fold higher solubility at $\mathrm{pH} 6.0$ and 7.0 than HPI-AW, respectively. These results clearly indicated that the hot extraction was an effective

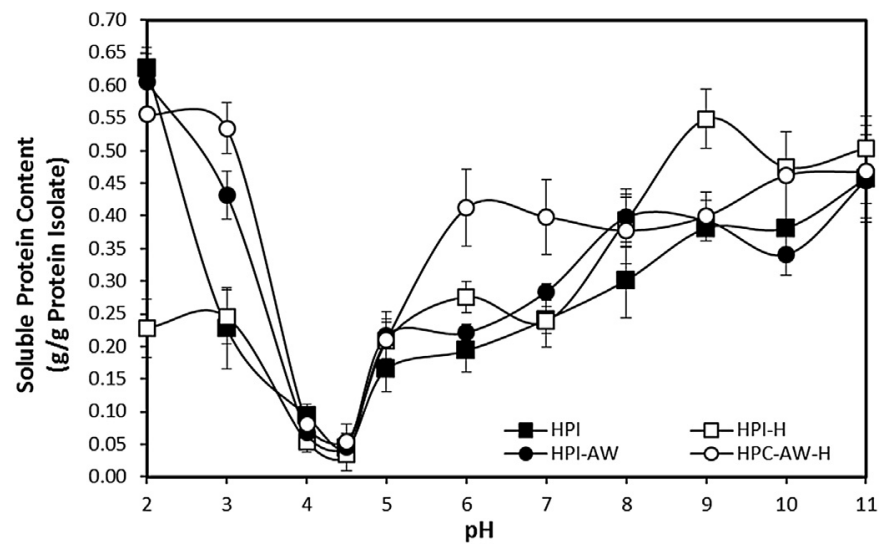

Fig. 1. pH-solubility profiles of different hazelnut meal protein extracts. treatment to increase solubility of hazelnut proteins. However, the solubility profile obtained for HPC-AW-H at acidic, neutral and alkaline $\mathrm{pH}$ values suggested that the combinational application of acetone washing and hot extraction was the most effective treatment to increase protein solubility.

\subsection{Bioactive properties of isolated hazelnut meal proteins}

\subsubsection{Antioxidant potential of isolated proteins}

The TEAC and ORAC values of extracts were significantly different from each other and varied between 158 and $365 \mathrm{mmol}$ Trolox/ $\mathrm{kg}$ and 219 and $461 \mathrm{mmol}$ Trolox/ $\mathrm{kg}$, respectively. The highest TEAC and ORAC values were obtained for HPC-AW-H, followed by those of HPI-AW, HPI-H and HPI. The HPI-H, HPI-AW and HPC-AW-H showed 1.2 and 1.5 fold, 1.6 and 1.8 fold, and 2.3 and 2.1 fold higher TEAC and ORAC than HPI, respectively. Thus, it is clear that the individual or combinational application of acetone washing and hot extraction has beneficial effects on antioxidant capacity based on free radical scavenging (FRS) of proteins. The acetone washing of meal was more effective on increased antioxidant capacity of extracts than the hot extraction, but the combinational application of acetone washing and hot extraction was the most effective method to improve the antioxidant capacity of proteins. The increased FRS based antioxidant activity of protein extracts by acetone and heat treatment could be related with their effects on protein unfolding and resulting increased accessibility to protein antioxidant groups such as those of histidine, tyrosine, phenylalanine, tryptophan and cysteine which were capable to donate protons to free radicals (Hu, McClements, \& Decker, 2003; Je, Park, \& Kim, 2004; Rajapakse, Mendis, Jung, Je, \& Kim, 2005). It is also possible that the slight differences in solubility of extracts at the $\mathrm{pH}$ of antioxidant activity measurements $(\mathrm{pH} 7.4)$ and removal of some prooxidants in the meal by acetone washing and heat denaturation contribute to the differences in FRS based antioxidant activity of the isolated protein. Further studies are also needed to understand the contribution of non-proteinous compounds including carbohydrate-phenolic complexes and polymeric phenolic compounds in antioxidant activity of extracts. HPCAW-H needs a particular attention since it has the highest bioactivity, but lowest purity.

On the other hand, the ICC of protein extracts varied between 60.7 and $126.7 \mathrm{mmol}$ EDTA $/ \mathrm{kg}$. The highest ICC was obtained for HPI-H followed by those of HPC-AW-H, HPI-AW and HPI. Although the ICC values were significantly different from each other at $P<0.05$, the HPI and HPI-AW had very similar ICC values. The ICC of HPC-AW-H was also only 1.3 fold lower than that of HPI-H and this revealed the limited contribution of acetone washing to improve ICC of proteins. In contrast, the HPI-H and HPC-AW-H obtained by hot extraction showed almost 2.1 and 1.6 fold higher ICCs than HPI and HPI-AW, respectively. The contribution of hot extraction in ICC of proteins should be related with the specific conformational changes of heating in areas accommodating iron binding groups. It seemed that the heating unburied and exposed the iron binding 

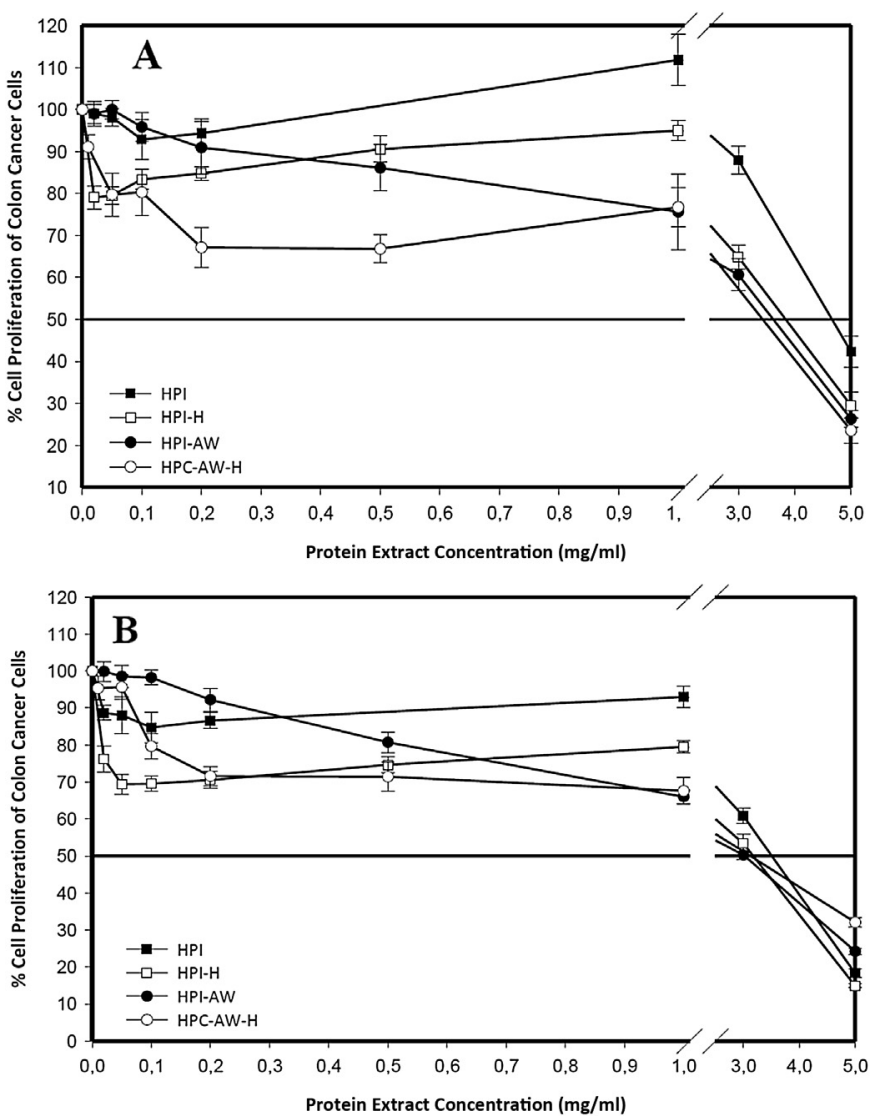

Fig. 2. Antiproliferative activities of hazelnut meal protein extracts for $48 \mathrm{~h}(\mathrm{~A})$ and $72 \mathrm{~h}(\mathrm{~B})$ incubations.

groups such as those of basic amino acids like lysine, histidine and arginine and those of acidic amino acids like aspartate and glutamate (Rajapakse et al., 2005; Saiga, Tanabe, \& Nishimura, 2003). This is an interesting finding suggesting the selective effects of acetone and heat treatment on protein conformation and resulting bioactivity.

\subsubsection{Antiproliferative activity of isolated proteins}

The anticancerogenic potential of different hazelnut protein extracts was determined by measuring their antiproliferative activity on CCC221/DLD-1 colon cancer cells after 48 and $72 \mathrm{~h}$ incubation periods (Fig. 2A and B). At low concentrations of HPI, HPI-H and HPC-AW-H, between 0 and $1 \mathrm{mg} / \mathrm{ml}$, the colon cancer cells incubated $48 \mathrm{~h}$ with these proteins resisted against inhibition and this caused fluctuations in their proliferation (Fig. 2A). A slight increase was observed in proliferation of colon cancer cells incubated $48 \mathrm{~h}$ with the indicated protein extracts up to $1 \mathrm{mg} / \mathrm{mL}$. However, this slight increase in cell proliferation did not occur in the presence of HPI-AW. On the other hand, all protein extracts showed a dose dependent antiproliferative activity when the extract concentration was increased from 1 to $5 \mathrm{mg} / \mathrm{mL}$. In general, HPC-AW-H, HPIAW and HPI-H become more effective on colon cancer cells than the HPI which is not very effective on colon cancer cells up to $3 \mathrm{mg} / \mathrm{mL}$. The lowest $\mathrm{IC}_{50}(48 \mathrm{~h})$ value was determined for $\mathrm{HPC}-\mathrm{AW}-\mathrm{H}$, but this value was only 0.2 and $0.4 \mathrm{mg} / \mathrm{mL}$ lower than those of HPI-AW and HPI-H, respectively. Thus, it appeared that the beneficial effect obtained in antiproliferative activity by the combinational application of acetone washing and hot extraction was not the result of an additional effect obtained by the individual application of these treatments. It seemed that the combinational application unburied

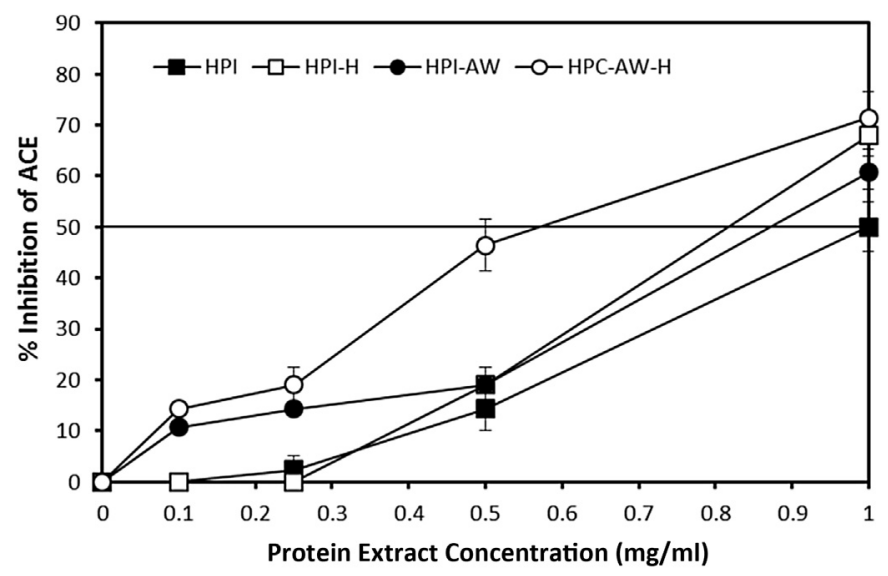

Fig. 3. Antihypertensive activities of hazelnut meal protein extracts.

some of the antiproliferative groups and/or available cell binding protein surfaces while destructing the others. The correlation coefficients $\left(r^{2}\right)$ determined between the measured TEAC and $\mathrm{IC}_{50}$ $(48 \mathrm{~h})$ values and ORAC and $\mathrm{IC}_{50}(48 \mathrm{~h})$ values $(-0,83$ and -0.98 , respectively) suggested a relation between antioxidant and antiproliferative activities of proteins. On the other hand, the increase of incubation period from 48 to $72 \mathrm{~h}$ caused $1.2,0.7,0.6$ and $0.3 \mathrm{mg} /$ $\mathrm{mL}$ reduction in $\mathrm{IC}_{50}(48 \mathrm{~h})$ of HPI, HPI-H, HPI-AW and HPC-AW-H, respectively. These reductions caused reaching of the extracts' antiproliferative activities almost to the same level with $72 \mathrm{~h}$ incubation (Fig. 2B). Moreover, the increased incubation of colon cancer cells with proteins considerably reduced the fluctuations caused by the slight proliferative effect of some isolates at low protein concentrations. It was interesting to note that the least and the most significant increase in antiproliferative activity by the increased incubation period occurred for HPC-AW-H and HPI, respectively. This result suggests the presence of similar antiproliferative mechanisms of protein in different extracts but variations in their affinities on colon cancer cells due to their different surface properties. The $\mathrm{IC}_{50}$ values determined for the hazelnut protein extracts were comparable to those determined for phenolic extracts for different cancer cells. For example, Xu and Chang (2012) reported $\mathrm{IC}_{50}$ values changing between 1.9 and $5.7 \mathrm{mg} / \mathrm{mL}$ for hydrophilic phenolic extracts of green pea, chickpea, lentil and yellow soybean tested against SW 480 colorectal adenocarcinoma cells. In contrast, Wu et al. (2011) and Dinicola et al. (2012) reported considerably low $\mathrm{IC}_{50}$ values for edible mushroom protein extracts $(0.5 \mathrm{mg} / \mathrm{mL})$ and red globe grape seed phenolic extracts $(0.05 \mathrm{mg} /$ $\mathrm{mL}$ ) tested against SW 480 colorectal cancer cells and HCT-8 human colorectal cancer cell lines, respectively.

\subsubsection{Antihypertensive activity of isolated proteins}

Antihypertensive activities of isolated protein were determined based on their ACE inhibitory capacities (Fig. 3). Protein extracts applied at increasing concentrations between 0.1 and $1 \mathrm{mg} / \mathrm{mL}$ inhibited the ACE activity at a dose dependent manner. The inhibition level in the presence of $1 \mathrm{mg} / \mathrm{mL}$ of different protein extracts changed between 50 and 70\%. The HPC-AW-H, which had 1.5-1.8 folds lower $\mathrm{IC}_{50}$ than the other proteins, showed the highest antihypertensive activity. The HPI-H and HPI-AW showed quite similar $\mathrm{IC}_{50}$ values which were almost 1.2 fold lower than that of HPI, respectively. These results clearly indicated the greater contribution of combinational application of acetone washing and hot extraction in improving antihypertensive properties of proteins than the individual application of these treatments. On the other hand, although the HPI showed the lowest inhibitory activity 
between concentrations of 0.1 and $1 \mathrm{mg} / \mathrm{mL}$, the increase of protein extract concentration from 1 to $5 \mathrm{mg} / \mathrm{mL}$ increased the inhibition caused by this extract almost 25\% (data not shown). For the other protein extracts, the dose dependency of the ACE inhibition was lost or weakened by increase of extract concentration from 1 to $5 \mathrm{mg} / \mathrm{mL}$. Thus, the ACE inhibition level of all isolated protein at $5 \mathrm{mg} / \mathrm{mL}$ became similar and changed at a narrow range between 70 and $80 \%$. These results clearly showed that the reactivity of protein in different extracts with ACE was different. It is also proved that the $20-30 \%$ of ACE was highly resistant to inhibition caused by the protein. However, the inhibition of a significant portion of ACE activity by hazelnut proteins suggested the considerable affinity of these proteins to the hydrophobic enzyme active site or anionic enzyme inhibitor binding site that is distinct from enzyme's catalytic site (Guang \& Phillips, 2009; Ryan, Ross, Bolton, Fitzgerald, \& Stanton, 2011). Moreover, it is also important to note that the ranking of the antihypertensive activities of extracts showed parallelism with those of FRS based antioxidant capacities and antiproliferative activities. The $r^{2}$ values determined between TEAC and $\mathrm{IC}_{50}$ for antihypertensive activity $\left(r^{2}:-0.919\right)$, ORAC and $\mathrm{IC}_{50}$ for antihypertensive activity $\left(r^{2}:-0.899\right)$ and $\mathrm{IC}_{50}$ values for antihypertensive and antiproliferative activities (for $48 \mathrm{~h})\left(r^{2}: 0.827\right.$ ) also supported the relation among these bioactive properties. In the literature, inconsiderable ACE inhibitory activities were reported for commercial soybean protein isolate (Lo \& Li-Chan, 2005), flaxseed meal protein isolate (Marambe, Shand, \& Wanasundara, 2008) and pumpkin meal protein isolate (Vaštag, Popović, Popović, Krimer, \& Peričin, 2011) unless they were hydrolyzed by proteases. The ACE inhibitory potential of hazelnut protein extracts was also higher than that of protease digested pea protein isolate $(1.36 \mathrm{mg} / \mathrm{mL})$ and comparable with that of protease digested whey protein isolate $(0.90 \mathrm{mg} / \mathrm{mL}$ ) (Vermeirssen, Van Camp, \& Verstraete, 2002).

\subsection{Functional properties of isolated hazelnut meal proteins}

\subsubsection{Water and oil absorption capacities of isolated proteins}

Due to their low water binding capacities, the hazelnut protein extracts showed no or very little WAC values (Table 2). Measurable WACs were obtained only for the heated protein extracts (HPI-H and HPC-AW-H) and this proved the modification of proteins during heating. However, no effect of acetone washing on WAC was determined. On the other hand, the OACs of protein extracts, varied between $7.4 \mathrm{~g} / \mathrm{g}$ and $9.4 \mathrm{~g} / \mathrm{g}$, showed no statistically significant differences $(P>0.05)$. Thus, it was clear that the acetone washing and/or hot extraction had no effect on OAC. Although the isolated hazelnut meal proteins showed poor WACs, their OACs are 1.3-2.5 fold higher than those of protein extracts obtained from flours of hazelnuts (90\% protein), almonds (93\% protein), pistachios (80\% protein) and peanuts ( $80-82.5 \%$ protein) obtained by alkaline extraction and dialysis (Sharma et al., 2010). The OACs of isolated hazelnut meal proteins were also comparable with those of non-GMO soy protein isolate (OAC: $8.23 \mathrm{~g} / \mathrm{g}$ ) and those of protein isolates from various red and green lentil cultivars (average OAC for 6 cultivars: $8.62 \mathrm{~g} / \mathrm{g}$ ) obtained with the same extraction and purification method (IEP) applied for HPI (Aydemir \& Yemenicioglu, 2013). The IEP protein isolates from flaxseed meal $(7.97 \mathrm{~g} / \mathrm{g}$ ) also showed similar OAC with the hazelnut meal protein isolates (Krause, Schultz, \& Dudek, 2002). However, it is worth to note that the OACs of isolated hazelnut meal proteins were $4-8$ fold higher than those of wheat protein isolate $(1.73 \mathrm{~g} / \mathrm{g}$ reported by Ahmedna, Prinyawiwatkul, and Rao (1999)), and those of commercial whey (1.59 g/g) and soy $(1.16 \mathrm{~g} / \mathrm{g})$ protein isolates reported by Aydemir and Yemenicioglu (2013).

\subsubsection{Emulsifying activity and emulsion stabilities of isolated proteins}

The highest EA was determined for HPI-AW, followed by HPI and HPC-AW-H with similar EAs, and HPI-H (Table 3). However, it was hard to report some dramatic differences among the EAs of protein extracts since the turbidities of their emulsions varied at a narrow range, between 302 and 340 NTU.

The HPI, HPI-H and HPC-AW-H showed quite similar ESs and maintained $80-100 \%$ of their turbidities in $30 \mathrm{~min}$. In contrast, the HPI-AW showed considerably lower ES than the other protein extracts and lost almost $40 \%$ of its turbidity within $30 \mathrm{~min}$. The higher ES of HPC-AW-H than HPI-AW and higher ES of HPI-H than HPI within 30 min showed the contribution of heat treatment applied during hot extraction in emulsifying properties of proteins. However, this was a limited contribution since all protein extracts showed very low ESs and lost almost $85 \%$ of their initial turbidities within $180 \mathrm{~min}$. Due to differences in emulsion formation conditions (type of oil, protein concentration and speed of homogenization), and in units and indices used in expression of emulsification properties, it is hard to compare the present results with those in most of the literature. However, it is worth to report that the EA and ES determined for the isolated hazelnut protein were comparable with those of commercial soy protein isolate and commercial whey protein isolate tested at the same conditions (Aydemir \& Yemenicioglu, 2013).

\subsubsection{Foaming activities and foam stabilities of isolated proteins}

The FAs of different protein extracts showed greater variation than EAs and changed between 7.1 and $18.9 \mathrm{~mL}$. The HPI-AW showed a very high FA which was almost 1.5 fold higher than those of HPI-H and HPC-AW-H, and 2.7 fold higher than that of HPI. Thus, it seemed that the modifications in surface activities of

Table 2

Functional properties of hazelnut meal protein extract (gelling and water and oil absorption capacities).

\begin{tabular}{|c|c|c|c|c|c|c|c|c|c|}
\hline \multirow[t]{2}{*}{ Protein extract } & \multicolumn{7}{|c|}{ Gelling properties at different isolate conc. $(\%, w / v)^{a}$} & \multirow[t]{2}{*}{ WAC $(g / g)$} & \multirow[t]{2}{*}{$\mathrm{OAC}(\mathrm{g} / \mathrm{g})$} \\
\hline & $1-8$ & 10 & 12 & 14 & 16 & 18 & 20 & & \\
\hline HPI & - & - & - & - & + & + & + & 0 & $9.1 \pm 0.97 \mathrm{a}^{\mathrm{b}}$ \\
\hline HPI-H & - & - & - & - & + & ++ & +++ LGC $^{\mathrm{c}}$ & $0.32 \pm 0.21 a$ & $9.4 \pm 0.75 a$ \\
\hline HPI-AW & - & - & - & - & + & ++ & +++ LGC & 0 & $8.8 \pm 0.15 a$ \\
\hline HPC-AW-H & - & + & ++ & $+++\mathrm{LGC}$ & +++ & +++ & +++ & $0.21 \pm 0.11 \mathrm{a}$ & $7.4 \pm 0.80 \mathrm{a}$ \\
\hline $\mathrm{WPI}^{\mathrm{d}}$ & - & + & ++ & +++ LGC & +++ & +++ & +++ & $0 \pm 0$ & $1.59 \pm 0.15 b$ \\
\hline $\mathrm{SPI}^{\mathrm{d}}$ & - & +++ LGC & +++ & +++ & +++ & +++ & +++ & $7.94 \pm 0.44 b$ & $1.16 \pm 0.05 b$ \\
\hline
\end{tabular}

a + : increased viscosity-no gelation; ++ : slush-like unfixed gel; +++ : fixed hard gel.

b Different letters in each column show significant differences at $P<0.05$.

c LGC: Least gelling concentration.

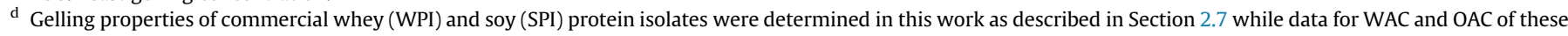
proteins were obtained from Aydemir and Yemenicioglu (2013) who tested these same commercial proteins at the same conditions used in this work. 
Table 3

Functional properties of hazelnut meal protein extracts (emulsifying and foaming activities and stabilities).

\begin{tabular}{|c|c|c|c|c|c|c|}
\hline Protein extract & $\mathrm{EA}(\mathrm{NTU})$ & $\mathrm{ES}_{30 \min }(\mathrm{NTU})$ & $\mathrm{ES}_{180 \min }(\mathrm{NTU})$ & $\mathrm{FA}(\mathrm{mL})$ & $\mathrm{FS}_{30 \min }(\mathrm{mL})$ & $\mathrm{FS}_{180 \min }(\mathrm{mL})$ \\
\hline HPI & $326 \pm 5 b c^{a}$ & $268 \pm 14 b$ & $53 \pm 5 b$ & $7.1 \pm 0.6 \mathrm{~cd}$ & $6.7 \pm 0.7 d$ & $5.5 \pm 0.6 b$ \\
\hline HPI-H & $302 \pm 6 d$ & $308 \pm 14 a$ & $47 \pm 10 b$ & $12.9 \pm 1.0 \mathrm{~b}$ & $12.3 \pm 0.4 b$ & $10.9 \pm 0.3 a$ \\
\hline HPI-AW & $340 \pm 3 b$ & $202 \pm 24 c$ & $42 \pm 16 b$ & $18.9 \pm 1.1 \mathrm{a}$ & $16.9 \pm 2.0 a$ & $6.9 \pm 3.2 \mathrm{ab}$ \\
\hline HPC-AW-H & $327 \pm 3 b c$ & $285 \pm 1 \mathrm{ab}$ & $46 \pm 1 b$ & $12.3 \pm 1.3 b$ & $11.3 \pm 0.9 b$ & $8.2 \pm 0.5 \mathrm{ab}$ \\
\hline $\mathrm{WPI}^{\mathrm{b}}$ & $365 \pm 15 a$ & $314 \pm 1 a$ & $105 \pm 3 a$ & $11.6 \pm 0.7 \mathrm{bc}$ & $10.1 \pm 1.5 b c$ & $0 \pm 0 c$ \\
\hline $\mathrm{SPI}^{\mathrm{b}}$ & $312 \pm 12 \mathrm{~cd}$ & $273 \pm 7 b$ & $62 \pm 6 b$ & $9.1 \pm 0.7 c$ & $7.9 \pm 0.8 \mathrm{~cd}$ & $5.6 \pm 0.1 b$ \\
\hline
\end{tabular}

a Different letters in each column show significant differences at $P<0.05$

b Data for whey protein isolate (WPI) and soy protein isolate (SPI) were obtained from Aydemir and Yemenicioglu (2013) who tested these proteins at the same conditions used in this work.

protein at air-water interface caused by acetone treatment alone were highly optimal to maximize the FA of HPI-AW. The significantly lower FA of HPC-AW-H than HPI-AW showed the adverse effect of hot extraction on foaming activity of protein obtained by acetone treated meal. However, 1.8 fold higher FA of HPI-H than HPI showed the beneficial effect of hot extraction alone in improving FA of proteins untreated with acetone. These results clearly showed the sharp differences created in surface properties of protein at airwater interface by combinational or individual application of acetone washing and hot extraction.

The FS of protein isolates at 30 min corresponded to almost $90 \%$ of their initial FAs and this clearly showed the stability of obtained foams. The limited changes in FS of HPI, HPI-H, and HPCAW-H in 180 min clearly proved the high resistances of these protein extracts' foams to destabilization. In contrast, the high initial FA gained by HPI-AW was not stable and it reduced almost by $63 \%$ during $180 \mathrm{~min}$ incubation. These results clearly showed the different factors affecting the foaming activities and stabilities. The HPI-AW also formed the least stable emulsions. Thus, it was clear that the acetone induced modifications in conformation of HPI-AW did not contribute to its ES and FS which were related with increased protein-protein interaction and formation of a thick and viscoelastic film at oil-water and air-water interfaces, respectively (Damodaran, 1996). The results obtained in this work for foaming properties of hazelnut meal protein extracts contradict with those obtained for hazelnut protein extract by Sharma et al. (2010). These authors did not report a considerable FA and FS for hazelnut protein extract obtained by alkaline extraction and dialysis from hazelnut flour. Sharma et al. (2010) attributed the poor foaming properties of hazelnut and some other nut proteins to their compact globular conformation which hided their surface active properties. Thus, it appeared that the higher foaming properties of hazelnut meal protein extracts are due to protein unfolding occurred during oil processing and heat treatment applied during extraction for protein modification. The FAs determined in this work for different isolated hazelnut meal proteins were also either comparable with or higher than those of protein isolates obtained from defatted meals of 6 lentil cultivars (average FA: $8.7 \mathrm{~mL}$ ), 4 chickpea cultivars (average FA: $10.98 \mathrm{~mL}$ ) and a non-GMO soybean cultivar $(6.5 \mathrm{~mL})$ prepared with the IEP method and those of commercial soy $(9.1 \mathrm{~mL})$ and whey $(11.6 \mathrm{~mL})$ protein isolates tested at the same conditions (concentration, $\mathrm{pH}$, speed of mixing) applied in the current study (Aydemir \& Yemenicioglu, 2013). The hazelnut protein isolates (except HPIAW) also had higher foam stabilities than $1 \%(\mathrm{w} / \mathrm{v})$ solutions of IEP pea protein isolate, broad bean protein isolate and lupin protein isolate which lost $25-30 \%$ of their initial foam volume at $\mathrm{pH}$ 7.0 within 30 min (Makri, Papalamprou, \& Doxastakis, 2005) and $1 \%$ solutions of commercial soy protein isolate and whey protein isolate which lost almost $38 \%$ and $100 \%$ of their initial foam volume at $\mathrm{pH} 7.0$ within $180 \mathrm{~min}$, respectively (Aydemir \& Yemenicioglu, 2013).

\subsubsection{Gel formation capacities of isolated proteins}

The gelling properties of isolated protein between 1 and 20\% $(\mathrm{w} / \mathrm{v})$ showed the limited gel formation capacity of hazelnut proteins. The highest gelling capacity was determined for HPC-AW-H which formed fixed gels at $14 \%$. The HPI-H and HPI-AW formed fixed gels at the protein concentration of $20 \%$, while HPI did not form any gel at the studied concentration range. It is well known that the unfolding and exposure of critical number of functional groups, such as hydrogen bonding and hydrophobic groups are the essential steps in the sol to gel state transformation mechanisms of proteins (Damodaran, 1996). Thus, these results supported our previous hypothesis that the acetone washing and hot extraction had possible roles in protein unfolding and exposing reactive groups responsible for the bioactive properties of hazelnut proteins. It is also once more proved that the modifications in protein conformation pronounce by the combinational application of acetone washing and heat treatment. The LGC of HPC-AW-H obtained from hazelnut meal is comparable with that of peanut $(14 \mathrm{w} /$ v) protein concentrate (Sharma et al., 2010), but it is still considerably lower than those of hazelnut $(12 \mathrm{w} / \mathrm{v})$, almond ( $6 \mathrm{w} / \mathrm{v})$, Brazil nut $(8 \mathrm{w} / \mathrm{v})$ and cashew nut $(8 \mathrm{w} / \mathrm{v})$ protein isolates or concentrates obtained from defatted nut flour with alkaline extraction and dialysis (Sharma et al., 2010). The LGC of HPC-AW-H is also lower than those of the commercial soy protein isolates $(10 \% \mathrm{w} / \mathrm{v})$ and whey protein isolates $(14 \% \mathrm{w} / \mathrm{v})$ tested in this work as reference proteins at the same conditions. These results clearly showed the poor gelling properties of isolated hazelnut meal proteins.

\subsection{Edible film making properties of isolated hazelnut meal proteins}

\subsubsection{Solubility of edible films}

The solubility profiles of different edible films obtained by changing protein extract concentration (10\% and $12.5 \%$ ) and heating period (30 min and $60 \mathrm{~min}$ ) of film making solutions are given at Fig. 4A-D. High protein solubility form films indicates low protein denaturation during film preparation and week interactions among film components, while low solubility indicates high protein denaturation and some considerable interactions among film components. The results obtained by $3 \mathrm{~h}$ incubation of films in distilled water showed that the films of hazelnut protein extracts were not water resistant and they disintegrated in water due to solubilization of part of their protein. However, in most of the extracts the use of suitable protein concentration and heating time could be effective to minimize the protein solubility of films and to improve their water resistances. For example, the use of $12.5 \%$ isolate concentration with $60 \mathrm{~min}$ heating period was the most effective procedure to reduce the protein solubility of films from all extracts. In contrast, the most soluble films were obtained from HPI-AW (10\%-60 min), followed by HPI-H (10\%-30) and HPC-AW-H (10\%-60 min). Thus, it was likely that the combinational application of high protein concentration and long heating period enhanced 

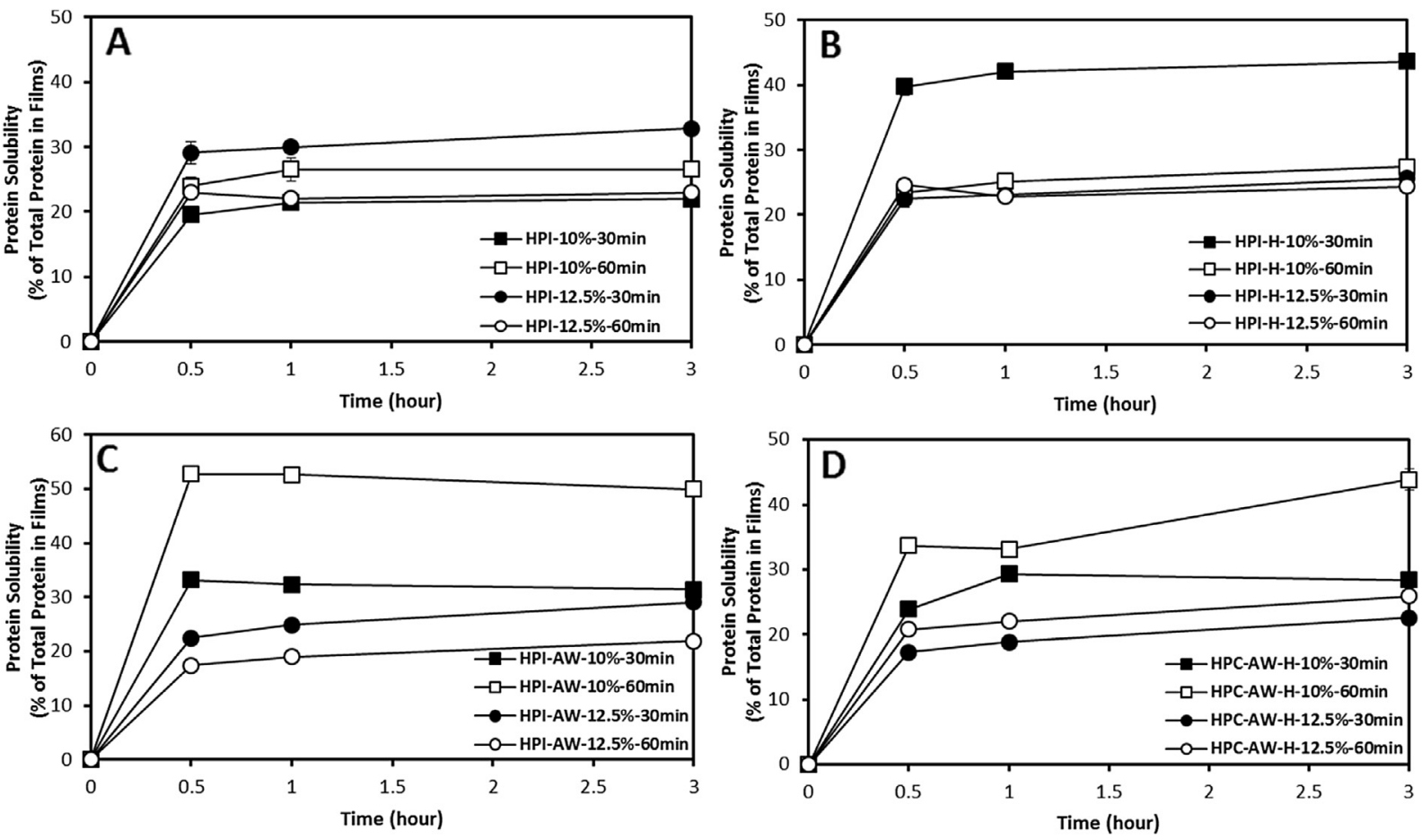

Fig. 4. Effects of protein concentration and heating applied during film making on water solubilities of edible films from hazelnut meal protein extracts.

the protein-protein interactions within the film matrix while it reduced the protein-solvent interactions. Moreover, it is clear that the individual or combinational application of acetone washing and hot extraction have no beneficial effects in controlling protein solubilization of edible films.

\subsubsection{Mechanical properties of edible films}

The elongation at break $(E)$ and tensile strength (TS) values of films obtained from different protein extracts were given at Fig. 5A and $\mathrm{B}$. In general, the use of different protein extracts and modifications in film making conditions caused considerable changes in mechanical properties of the films. For example, the increase of the extract concentration from $10 \%$ to $12.5 \%$ and the heating time from 30 min to 60 min during film making increased the $E$ of HPI, HPI-H and HPI-AW considerably. In contrast, the increase of isolate concentration and heating time caused a sharp reduction in $E$ of HPCAW-H. The overall $E$ measurements at different conditions showed that the most flexible films were formed by HPI ( $E$ between $62 \%$ and $144 \%$ ) followed by HPI-H, HPI-AW and HPC-AW-H. On the other hand, the change of the extract concentration and the heating time during film making caused limited or inconsiderable reductions in TSs of HPI and HPI-H, while TSs of HPI-AW and HPC-AW-H increased or reduced dramatically by change of film making conditions. The HPI-H gave the highest TSs (between 5.6 and 7.9 MPa) at different film making conditions while the films of HPI-AW and HPC-AW-H obtained at $10 \%$ extract concentration with 60 min heating gave the lowest TSs. These $E$ and TS measurements conducted at different film making conditions clearly showed that the use of HPI and HPI-H in film making was more advantageous than the use of HPI-AW and HPC-AW-H in obtaining flexible films with sufficient resistances against mechanical stresses. Thus, it is evident that the use of extracts obtained by acetone washing alone or in combination with hot extraction during protein extraction is not beneficial when hazelnut proteins will be employed in edible film production.

\subsubsection{Color of edible films}

The photos of films obtained at the extract concentration of $12.5 \%$ showed a color change in films from yellowish to brownish and brownish to reddish depending on type of extract used in film making and change of heating time used for film making solutions (Fig. 6). However, all films were transparent and did not contain any haze or cloud indicating the insolubilization of proteins before drying of films. As expected, the increase of heating time from 30 min to 60 min during film making caused visually detectable increases in the darkness of all films. The darkening observed by increased heating in HPI and HPI-H films were limited and did not cause any significant reductions in $L^{*}$ values of the films (Table 4 ) $(P>0.05)$. In contrast, increase of heating time during film making caused apparent darkening and significant reductions in $L^{*}$ values of HPI-AW and HPC-AW-H films $(P<0.05)$. The increased heating time was not effective on film $a^{*}$ values which represented the redness-greenness of the films while it caused significant reductions in film $b^{*}$ values (except HPI films) which represent yellowness-blueness. The overall results showed that the HPI gave the lightest colored films at both $30 \mathrm{~min}$ and $60 \mathrm{~min}$ heating period, followed by HPI-AW and HPC-AW-H films obtained by $30 \mathrm{~min}$ heating. In contrast, films of HPI-H were quite dark at both heating conditions.

\subsection{Molecular properties of isolated hazelnut meal proteins}

\subsubsection{Classical SDS-PAGE patterns of isolated proteins}

The classical 1D SDS-PAGE patterns of protein extracts at different concentrations, 5 and $10 \mathrm{mg} / \mathrm{mL}$, are given in Fig. 7A. The molecular weight (MW) of protein in different extracts changed at a narrow range between 14.4 and $48.5 \mathrm{kDa}$. In fact, it could be reported that the majority of the hazelnut proteins were low MW ones concentrated between 20 and $25 \mathrm{kDa}$. The protein extracts gave similar protein band patterns, but different band widths and intensities depending on protein extract concentration. For 

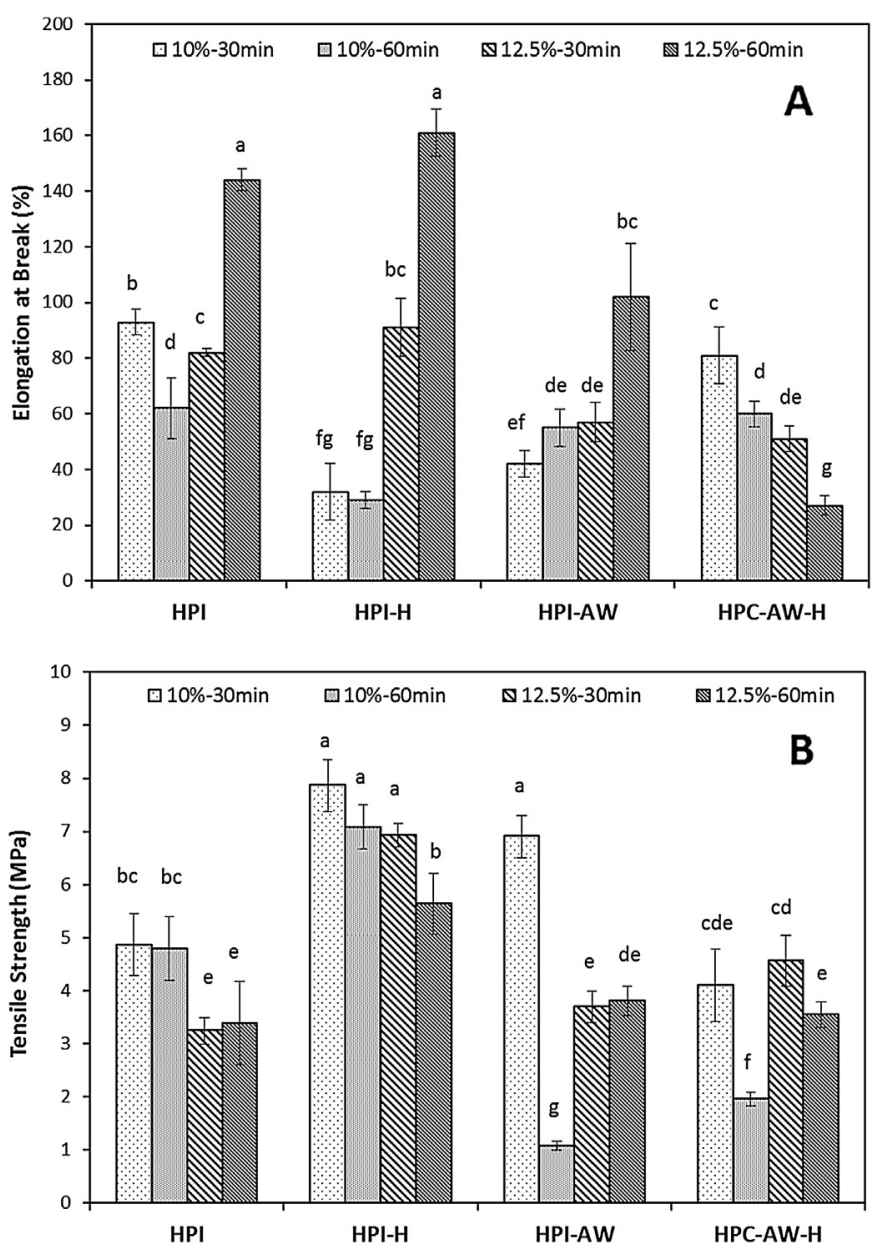

Fig. 5. Mechanical properties of edible films obtained from hazelnut meal protein extracts (A: elongation at break; B: tensile strength).

example, HPI-H, HPI-AW and HPI gave almost similar band widths and intensities at the concentration of $5 \mathrm{mg} / \mathrm{mL}$, while HPC-AW-H at the same concentration gave weaker and thinner bands than the other extracts. This result proved that the acetone treated proteins were more heat labile than the untreated proteins, and it explained the lower total protein content of HPC-AW-H than the other isolates. As expected, the protein bands become more intense at the protein extract concentration of $10 \mathrm{mg} / \mathrm{mL}$. The increase of protein concentration caused clearly identifiable increases in the band widths of most HPI-H, HPI-AW and HPC-AW-H bands, while only slight increases were observed in the band widths of HPI fractions. These results suggested some limited modifications and a limited increased heterogeneity in acetone and heat treated protein
Table 4

Color of edible films obtained from hazelnut meal protein extracts.

\begin{tabular}{lllll}
\hline Protein extract & $\begin{array}{l}\text { Heating time } \\
\text { (min) }\end{array}$ & $L^{*}$ & $a^{*}$ & $b^{*}$ \\
\hline HPI-12.5\% & 30 & $53.3 \pm 0.5 \mathrm{a}^{\mathrm{a}}$ & $21.3 \pm 0.6 \mathrm{a}$ & $34.2 \pm 0.4 \mathrm{ab}$ \\
& 60 & $53.2 \pm 4.4 \mathrm{a}$ & $22.3 \pm 3.4 \mathrm{a}$ & $34.5 \pm 1.5 \mathrm{a}$ \\
HPI-H-12.5\% & 30 & $40.0 \pm 1.1 \mathrm{~d}$ & $29.0 \pm 1.1 \mathrm{~b}$ & $28.7 \pm 1.3 \mathrm{c}$ \\
& 60 & $37.7 \pm 1.0 \mathrm{~d}$ & $28.1 \pm 0.4 \mathrm{~b}$ & $25.7 \pm 1.0 \mathrm{~d}$ \\
HPI-AW-12.5\% & 30 & $48.0 \pm 5.3 \mathrm{~b}$ & $29.2 \pm 3.8 \mathrm{~b}$ & $34.5 \pm 0.5 \mathrm{a}$ \\
& 60 & $41.2 \pm 1.7 \mathrm{~cd}$ & $31.5 \pm 0.5 \mathrm{~b}$ & $32.0 \pm 1.6 \mathrm{~b}$ \\
HPC-AW-H-12.5\% & 30 & $45.8 \pm 1.2 \mathrm{bc}$ & $29.2 \pm 0.9 \mathrm{~b}$ & $33.0 \pm 0.5 \mathrm{ab}$ \\
& 60 & $38.8 \pm 1.2 \mathrm{~d}$ & $30.5 \pm 0.5 \mathrm{~b}$ & $28.5 \pm 1.8 \mathrm{c}$ \\
\hline
\end{tabular}

${ }^{a}$ Different letters in each column show significant differences at $P<0.05$.

fractions. However, it seems that the significant differences in bioactivity, functionality and film making properties of protein extracts are not due to major differences in MW of their monomeric fractions but due to differences in their conformations caused by the acetone washing and/or hot extraction. The SDS-PAGE of different nut proteins including hazelnut proteins has been previously studied by Sathe et al. (2009) with details. These authors solubilized nut proteins from defatted nut flour and then investigated their SDS-PAGE profiles without applying isoelectric precipitation of proteins. There were some differences in the band intensities and profiles obtained by these authors and those obtained by the current study for hazelnut proteins, but concentration of most intensive protein bands determined by Sathe et al. (2009) between 20 and $30 \mathrm{kDa}$ (close to $20 \mathrm{kDa}$ ) compared well with the results of current study.

\subsubsection{2-D electrophoresis patterns of isolated proteins}

The MW patterns and isoelectric properties of one of the extracts were also further characterized by using 2D electrophoresis. The HPI-AW was particularly selected for this purpose since it was not heat treated but acetone washed to remove oxidized polymeric phenolic substances and lipid oxidation products which could form complexes with proteins and mask their charges. The 2D pattern of HPI-AW is given in Fig. 7B. The results of pI profiles clearly showed the great variations in isoelectric profiles of hazelnut proteins. The majority of the high MW proteins had pI between 5.0 and 5.4, while low MW fractions concentrated between pI 7.0 and 8.5. Sathe et al. (2009) applied isoelectric focusing of hazelnut proteins extracted from defatted flour with Tris- $\mathrm{HCl}$ buffer at $\mathrm{pH} 8.1$ found that these proteins migrated mainly around pI 5.85 (between pI $>5.2$ and pI $<6.55$ ). Moreover, these authors did not determine any minor hazelnut protein fractions between pI 7.0 and 8.5. However, it is hard to understand the reasons of differences between results of Sathe et al. (2009) and the current work which uses different material (defatted and acetone treated meal) and different methods for extraction, purification and isoelectric focusing of protein. On the other hand, the MW pattern of HPI-AW proteins obtained by

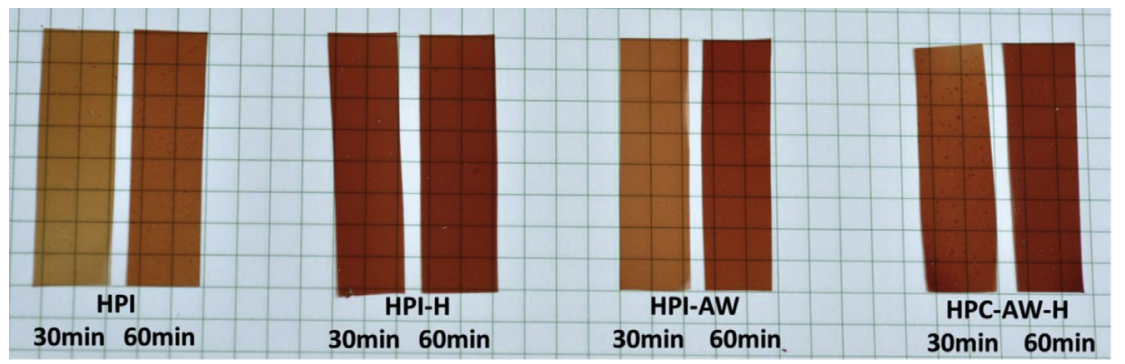

Fig. 6. Photos of edible films obtained from hazelnut meal protein extracts (protein extract concentration: 12.5\%). 


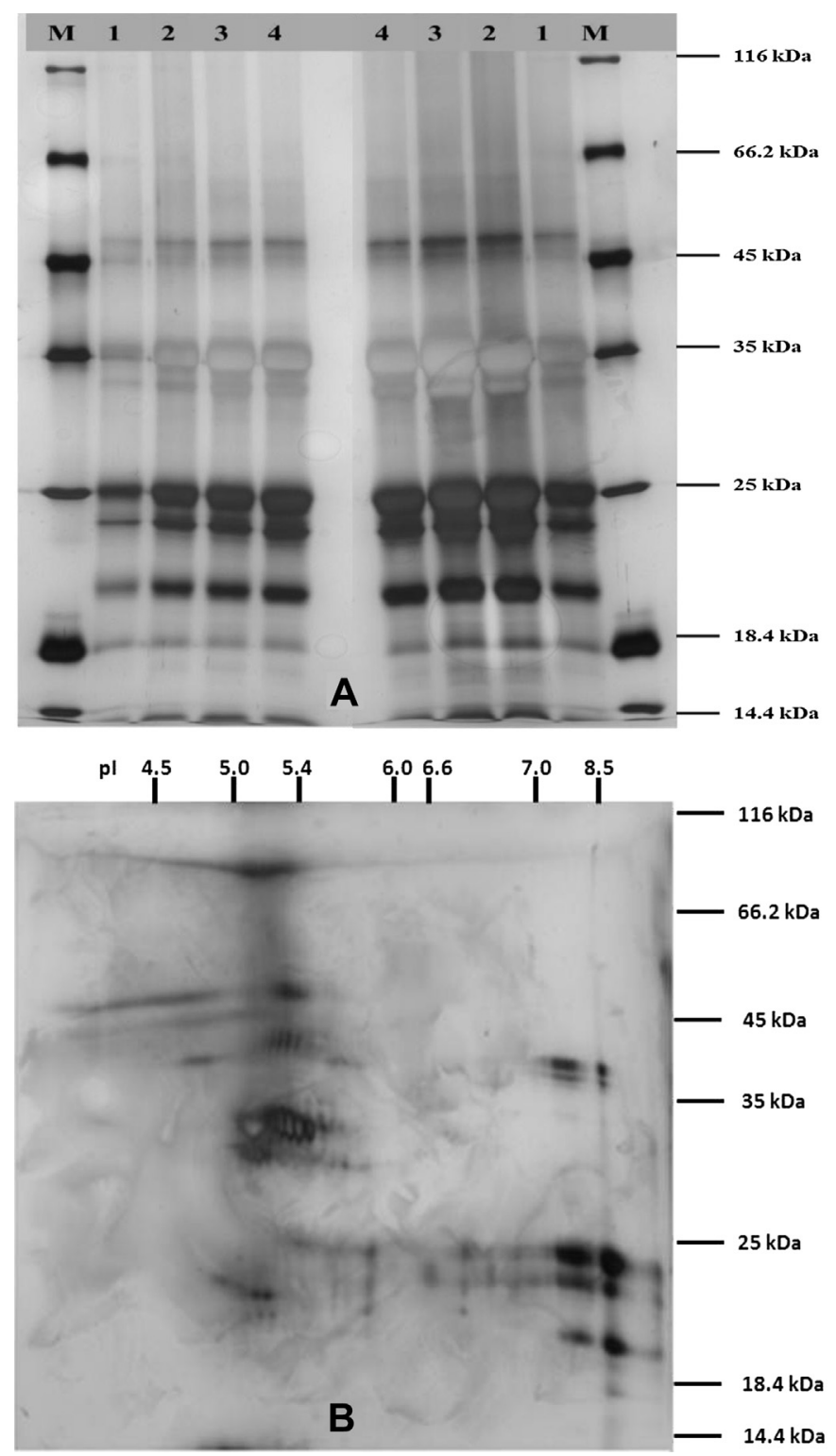

Figure 7. Molecular properties of hazelnut meal protein extracts (For classical SDSPAGE in A: 1: HPC-AW-H, 2: HPI-AW, 3: HPI-H, 4: HPI; protein concentrations of $M$, 1,2,3,4 (left) and 4,3,2,1,M (right) were 5 and $10 \mathrm{mg} / \mathrm{mL}$, respectively). For 2D electrophoresis in B: pI (migration: vertical) MW (migration: horizontal) patterns of HPIAW.

the 2D electrophoresis was quite similar with that obtained with the classical SDS-PAGE. However, the $80 \mathrm{kDa}$ protein band observed during 2D electrophoresis was not detected during classical SDSPAGE of hazelnut proteins. The classical SDS-PAGE involves the treatment of sample with SDS and a heating step which is essential to effectively transform quaternary structures to their tertiary structures. However, this procedure conducted at harsh conditions might sometimes cause loss of some protein fractions due to denaturation and insolubilization. The 2D electrophoresis does not involve the heating step and it is a better procedure to monitor the full MW patterns of proteins.

In conclusion, this study clearly showed the bioactive, functional and edible film making properties of hazelnut meal proteins. The acetone washing and hot extraction of meals were quite beneficial to improve the bioactive properties of protein extracts based on antioxidant capacity, antiproliferative activity on cancer cells and antihypertensive activities. The acetone washing and hot extraction also improved the gelling and solubility properties of hazelnut protein extracts, but got limited beneficial effects in improving edible film making properties. Due to their high bioactivity, the hazelnut protein extracts could be very suitable to develop novel functional foods and to contribute to human health. It might be quite interesting to enrich hazelnut cream and hazelnut containing confectionary with bioactive hazelnut proteins and develop novel hazelnut protein rich functional beverages such as hazelnut milk. However, it is quite important to support these studies with more solid animal or human tests and understand the real magnitudes of potential health benefits of hazelnut proteins. The low water absorption capacity, gelation capacity and emulsion stability were the limitations of the technological capacity of isolated hazelnut meal proteins. However, good foaming properties and oil absorption capacities might still be exploited to obtain beneficial effects in many different food systems. For example, flavored hazelnut protein solutions could be used in hot and cold drink foams prepared just before serving or they could be tested to improve textural properties of foam type foods such as ice-cream. The hazelnut meal proteins showed good film forming abilities and gave flexible, water soluble edible films depending of processing conditions. These films might be suitable for bioactive packaging which involves incorporating nutrients and bioactive compounds into film forming solution and applying it onto surface of suitable food by dipping, spraying or brushing. However, the film making should be conducted at mild heating conditions to avoid darkening of the films. Further studies are continuing in our laboratories to employ hazelnut protein extracts in different food systems and to develop bioactive or active edible films from hazelnut proteins. This work clearly showed the importance of hazelnut meal as source of value added protein based products and food ingredients.

\section{Acknowledgment}

This project was funded by the Research Foundation of Izmir Institute of Technology (IZTECH). We appreciate the Izmir Institute of Technology, Biotechnology and Bioengineering Research and Application Center for providing their laboratory facilities.

\section{References}

Aewsiri, T., Benjakul, S., Visessanguan, W., Eun, J. B., Wierenga, P. A., \& Gruppen, H. (2009). Antioxidative activity and emulsifying properties of cuttlefish skin gelatin modified by oxidised phenolic compounds. Food Chemistry, 117(1), 160168.

Ahmedna, M., Prinyawiwatkul, W., \& Rao, R. M. (1999). Solubilized wheat protein isolate: functional properties and potential food applications. Journal of Agricultural and Food Chemistry, 47(4), 1340-1345.

Alasalvar, C., Karamac, M., Kosinska, A., Rybarczyk, A., Shahidi, F., \& Amarowicz, R. (2009). Antioxidant activity of hazelnut skin phenolics. Journal of Agricultural and Food Chemistry, 57(11), 4645-4650.

Alonso, A., Beunza, J. J., Bes-Rastrollo, M., Pajares, R. M., \& Martínez-González, M.Á (2006). Vegetable protein and fiber from cereal are inversely associated with the risk of hypertension in a Spanish Cohort. Archives of Medical Research, 37(6), 778-786.

AOAC. (1998). Official methods of analysis. Washington, DC: Association of Official Analytical Chemists.

Arcan, I., \& Yemenicioglu, A. (2007). Antioxidant activity of protein extracts from heat-treated or thermally processed chickpeas and white beans. Food Chemistry, 103(2), 301-312.

Arcan, I., \& Yemenicioglu, A. (2010). Effects of controlled pepsin hydrolysis on antioxidant potential and fractional changes of chickpea proteins. Food Research International, 43(1), 140-147.

ASTM. (2002). Standard test method for tensile properties of thin plastic sheetingD882-02. In ASTM (Ed.), Annual book of American standard testing methods. Philadelphia, PA.

Aydemir, L. Y., \& Yemenicioglu, A. (2013). Potential of Turkish Kabuli type chickpea and green and red lentil cultivars as source of soy and animal origin functional protein alternatives. LWT - Food Science and Technology, 50(2), 686-694.

Blum, H., Beier, H., \& Gross, H. J. (1987). Improved silver staining of plant proteins RNA and DNA in polyacrylamide gels. Electrophoresis, 8(2), 93-99. 
Boye, J., Zare, F., \& Pletch, A. (2010). Pulse proteins: processing, characterization, functional properties and applications in food and feed. Food Research International, 43(2), 414-431.

Brandts, J. F., \& Hunt, L. (1967). Thermodynamics of protein denaturation. III Denaturation of ribonuclease in water and in aqueous urea and aqueous ethanol mixtures. Journal of the American Chemical Society, 89(19), 4826-4838.

Bräuer, S., Meister, F., Gottlöber, R.-P., \& Nechwatal, A. (2007). Preparation and thermoplastic processing of modified plant proteins. Macromolecular Materials and Engineering, 292(2), 176-183.

Chee, K. L., Ling, H. K., \& Ayob, M. K. (2012). Optimization of trypsin-assisted extraction, physico-chemical characterization, nutritional qualities and functionalities of palm kernel cake protein. LWT - Food Science and Technology, 46(2), 419-427.

Damodaran, S. (1996). Amino acids, peptides and proteins. In O. Fennema (Ed.), Food chemistry (4th ed.). (pp. 321-429) New York: Marcel Dekker.

Demiryürek, K., Ceyhan, V., \& Bozoğlu, M. (2012). Risk attitudes of organic and conventional hazelnut producers in Turkey. Human and Ecological Risk Assessment: An International Journal, 18(2), 471-482.

Dinicola, S., Cucina, A., Pasqualato, A., D’Anselmi, F., Proietti, S., Lisi, E., et al. (2012) Antiproliferative and apoptotic effects triggered by grape seed extract (GSE) versus epigallocatechin and procyanidins on colon cancer cell lines. International Journal of Molecular Sciences, 13(1), 651-664.

Doğan, G., \& Erdem, M. (2010). Effects of hazelnut meal levels on growth performance, feed utilization and digestibility in juveline rainbow trout (Oncorhynchus mykiss). Turkish Journal of Fisheries and Aquatic Sciences, 10, 181-186.

Dormont, D. (2002). Prion diseases: pathogenesis and public health concerns. FEBS Letters, 529(1), 17-21.

Dunn, M. J. (1989). Electrophoretic analysis methods. In E. L. V. Haris, \& S. Anga (Eds.), Protein purification methods: A practical approach (pp. 18-40). New York: Oxford University Pres Inc.

Emre, Y., Sevgili, H., \& Șanlı, M. (2008). A preliminary study on the utilization of hazelnut meal as a substitute for fish meal in diets of European sea bass (Dicentrarchus labrax L.). Aquaculture Research, 39(3), 324-328.

Erener, G., Ak, F. B., \& Ocak, N. (2009). A study on feeding hazelnut kernel oil meal as a protein source for broiler chickens. Animal Science Journal, 80(3), 305-309.

FAO. (2002). FAO animal production and health proceedings. In Protein sources for the animal feed industry. Bangkok: Food and Agricultural Organization of the United Nations.

Guang, C., \& Phillips, R. D. (2009). Plant food-derived angiotensin I converting enzyme inhibitory peptides. Journal of Agricultural and Food Chemistry, 57(12), 5113-5120.

Hu, M., McClements, D. J., \& Decker, E. A. (2003). Lipid oxidation in corn oil-in-water emulsions stabilized by casein, whey protein isolate, and soy protein isolate. Journal of Agricultural and Food Chemistry, 51(6), 1696-1700.

ISO. (2000). Oilseeds - Determination of moisture and volatile matter content. ISO 665:2000(E)

Jamdar, S. N., Rajalakshmi, V., Pednekar, M. D., Juan, F., Yardi, V., \& Sharma, A. (2010). Influence of degree of hydrolysis on functional properties, antioxidant activity and ACE inhibitory activity of peanut protein hydrolysate. Food Chemistry, 121(1), 178-184.

Jang, S. A., Lim, G. O., \& Bin Song, K. (2011). Preparation and mechanical properties of edible rapeseed protein films. Journal of Food Science, 76(2), C218-C223.

Je, J. Y., Park, P. J., \& Kim, S. K. (2004). Radical scavenging activity of hetero-chitooligosaccharides. European Food Research and Technology, 219(1), 60-65.

Jenkins, D. J., Kendall, C. W., Jackson, C.-J. C., Connelly, P. W., Parker, T., Faulkner, D., et al. (2002). Effects of high- and low-isoflavone soyfoods on blood lipids, oxidized LDL, homocysteine, and blood pressure in hyperlipidemic men and women. The American Journal of Clinical Nutrition, 76(2), 365-372.

Karim, A. A., \& Bhat, R. (2009). Fish gelatin: properties, challenges, and prospects as an alternative to mammalian gelatins. Food Hydrocolloids, 23(3), 563-576.

Krause, J.-P., Schultz, M., \& Dudek, S. (2002). Effect of extraction conditions on composition, surface activity and rheological properties of protein isolates from flaxseed (Linum usitativissimum L.). Journal of the Science of Food and Agriculture, 82(9), 970-976.

Lo, W. M. Y. \& Li-Chan, E. C. Y. (2005). Angiotensin I converting enzyme inhibitory peptides from in vitro pepsin-pancreatin digestion of soy protein. Journal of Agricultural and Food Chemistry, 53(9), 3369-3376.

Lomascolo, A., Uzan-Boukhris, E., Sigoillot, J. C., \& Fine, F. (2012). Rapeseed and sunflower meal: a review on biotechnology status and challenges. Applied Microbiology and Biotechnology, 95(5), 1105-1114.

Makri, E., Papalamprou, E., \& Doxastakis, G. (2005). Study of functional properties of seed storage proteins from indigenous European legume crops (lupin, pea, broad bean) in admixture with polysaccharides. Food Hydrocolloids, 19(3), 583594.

Manamperi, W. A. R., Wiesenborn, D. P., Chang, S. K. C., \& Pryor, S. W. (2011). Effects of protein separation conditions on the functional and thermal properties of canola protein isolates. Journal of Food Science, 76(3), E266-E273.

Marambe, P. W. M. L. H. K., Shand, P. J., \& Wanasundara, J. P. D. (2008). An in-vitro investigation of selected biological activities of hydrolysed flaxseed (Linum usitatissimum L.) proteins. Journal of the American Oil Chemists' Society, 85(12), $1155-1164$

Megías, C., Pedroche, J., Yust, M. M., Girón-Calle, J., Alaiz, M., Millán, F., et al. (2008). Production of copper-chelating peptides after hydrolysis of sunflower proteins with pepsin and pancreatin. LWT - Food Science and Technology, 41(10), 19731977.
Moure, A., Sineiro, J., Domínguez, H., \& Parajó, J. C. (2006). Functionality of oilseed protein products: a review, Food Research International, 39(9), 945-963.

Neto, V. Q., Narain, N., Silva, J. B., \& Bora, P. S. (2001). Functional properties of raw and heat processed cashew nut (Anacardium occidentale, L.) kernel protein isolates. Food/Nahrung, 45(4), 258-262.

Ng, K. L., Ayob, M. K., Said, M., Osman, M. A., \& Ismail, A. (2013). Optimization of enzymatic hydrolysis of palm kernel cake protein (PKCP) for producing hydrolysates with antiradical capacity. Industrial Crops and Products, 43, 725731.

Ogunwolu, S. O., Henshaw, F. O., Mock, H.-P., Santros, A., \& Awonorin, S. O. (2009). Functional properties of protein concentrates and isolates produced from cashew (Anacardium occidentale L.) nut. Food Chemistry, 115(3), 852-858.

Orliac, O., Rouilly, A., Silvestre, F., \& Rigal, L. (2002). Effects of additives on the mechanical properties, hydrophobicity and water uptake of thermo-moulded films produced from sunflower protein isolate. Polymer, 43(20), 5417-5425.

Piskin, O., Ozcan, M. A., Ozsan, G. H., Ates, H., Demirkan, F., Alacacioglu, I., et al (2007). Synergistic effect of imatinib mesylate and fludarabine combination on Philadelphia chromosome-positive chronic myeloid leukemia cell lines. Turkish Journal of Hematology, 24, 23-27.

Rajapakse, N., Mendis, E., Jung, W.-K., Je, J.-Y., \& Kim, S.-K. (2005). Purification of a radical scavenging peptide from fermented mussel sauce and its antioxidant properties. Food Research International, 38(2), 175-182.

Ramos, C. M. P., \& Bora, P. S. (2005). Functionality of succinylated Brazil nut (Bertholletia excelsa HBK) kernel globulin. Plant Foods for Human Nutrition (Formerly Qualitas Plantarum), 60(1), 1-6.

Re, R., Pellegrini, N., Proteggente, A., Pannala, A., Yang, M., \& Rice-Evans, C. (1999). Antioxidant activity applying an improved ABTS radical cation decolorization assay. Free Radical Biology and Medicine, 26(9-10), 1231-1237.

Reddy, N., Jiang, Q., \& Yang, Y. (2012). Preparation and properties of peanut protein films crosslinked with citric acid. Industrial Crops and Products, 39(0), 26-30.

Roe, S. (2001). Protein purification applications: A practical approach. Oxford University Press.

Ryan, J. T., Ross, R. P., Bolton, D., Fitzgerald, G. F., \& Stanton, C. (2011). Bioactive peptides from muscle sources: meat and fish. Nutrients, 3(9), 765-791.

Saiga, A., Tanabe, S., \& Nishimura, T. (2003). Antioxidant activity of peptides obtained from porcine myofibrillar proteins by protease treatment. Journal of Agricultural and Food Chemistry, 51(12), 3661-3667.

Salgado, P. R., Molina Ortiz, S. E., Petruccelli, S., \& Mauri, A. N. (2010). Biodegradable sunflower protein films naturally activated with antioxidant compounds. Food Hydrocolloids, 24(5), 525-533.

Salgado, P. R., Ortiz, S. E. M., Petruccelli, S., \& Mauri, A. N. (2012). Functional food ingredients based on sunflower protein concentrates naturally enriched with antioxidant phenolic compounds. Journal of the American Oil Chemists' Society, 89(5), 825-836.

Sathe, S. K., Venkatachalam, M., Sharma, G. M., Kshirsagar, H. H., Teuber, S. S., \& Roux, K. H. (2009). Solubilization and electrophoretic characterization of select edible nut seed proteins. Journal of Agricultural and Food Chemistry, 57(17), $7846-7856$.

Shalaby, S. M., Zakora, M., \& Otte, J. (2006). Performance of two commonly used angiotensin-converting enzyme inhibition assays using FA-PGG and HHL as substrates. Journal of Dairy Research, 73(2), 178-186.

Sharma, G. M., Su, M., Joshi, A. U., Roux, K. H., \& Sathe, S. K. (2010). Functional properties of select edible oilseed proteins. Journal of Agricultural and Food Chemistry, 58(9), 5457-5464.

Swamylingappa, B., \& Srinivas, H. (1994). Preparation and properties of protein isolate from hexane-acetic acid treated commercial soybean meal. Journal of Agricultural and Food Chemistry, 42(12), 2907-2911.

Sze-Tao, K. W. C., \& Sathe, S. K. (2000). Walnuts (Juglans regia L.): proximate composition, protein solubility, protein amino acid composition and protein in vitro digestibility. Journal of the Science of Food and Agriculture, 80(9), 13931401.

Thakur, M., \& Hurburgh, C. (2007). Quality of US soybean meal compared to the quality of soybean meal from other origins. Journal of the American Oil Chemists' Society, 84(9), 835-843.

Tsai, P. J., \& She, C. H. (2006). Significance of phenol-protein interactions in modifying the antioxidant capacity of peas. Journal of Agricultural and Food Chemistry, 54(22), 8491-8494.

Vaštag, Ž., Popović, L., Popović, S., Krimer, V., \& Peričin, D. (2011). Production of enzymatic hydrolysates with antioxidant and angiotensin-I converting enzyme inhibitory activity from pumpkin oil cake protein isolate. Food Chemistry, 124(4), 1316-1321.

Vermeirssen, V., Van Camp, J., \& Verstraete, W. (2002). Optimisation and validation of an angiotensin-converting enzyme inhibition assay for the screening of bioactive peptides. Journal of Biochemical and Biophysical Methods, 51(1), 75-87.

Wu, J. P. Aluko, R. E. \& Muir, A. D. (2009). Production of angiotensin I-converting enzyme inhibitory peptides from defatted canola meal. Bioresource Technology, $100(21), 5283-5287$

Wu, J.-Y., Chen, C.-H., Chang, W.-H., Chung, K.-T., Liu, Y.-W., Lu, F.-J., et al. (2011) Anti-cancer effects of protein extracts from Calvatia lilacina, Pleurotus ostreatus and Volvariella volvacea. Evidence-Based Complementary and Alternative Medicine, 2011.

Xu, B. J., \& Chang, S. K. C. (2007). A comparative study on phenolic profiles and antioxidant activities of legumes as affected by extraction solvents. Journal of Food Science, 72(2), S159-S166. 
Xu, B., \& Chang, S. K. C. (2012). Comparative study on antiproliferation properties and cellular antioxidant activities of commonly consumed food legumes against nine human cancer cell lines. Food Chemistry, 134(3), 12871296.

Xu, Y. X., \& Hanna, M. A. (2011). Nutritional and anti-nutritional compositions of defatted Nebraska hybrid hazelnut meal. International Journal of Food Science and Technology, 46(10), 2022-2029.
Yalcin, H., Toker, O. S., \& Dogan, M. (2012). Effect of oil type and fatty acid composition on dynamic and steady shear rheology of vegetable oils. Journal of Oleo Science, 61(4), 181-187.

Yoshie-Stark, Y., Wada, Y., Schott, M., \& Wäsche, A. (2006). Functional and bioactive properties of rapeseed protein concentrates and sensory analysis of food application with rapeseed protein concentrates. LWT - Food Science and Technology, 39(5), 503-512. 